\title{
Binderless Bark Particleboard Made from Gelam (Melaleuca viridiflora Sol. ex Gaertn.) Bark Waste: The Effect of the Pressing Temperature on Its Mechanical and Physical Properties
}

\author{
Eva Oktoberyani Christy, ${ }^{\mathrm{a}, \mathrm{b}, *}$ Soemarno, ${ }^{\mathrm{c}}$ Sumardi Hadi Sumarlan, ${ }^{\mathrm{d}}$ and \\ Agoes Soehardjono ${ }^{\mathrm{e}}$
}

\begin{abstract}
This study investigated the effects of the pressing temperature on the mechanical and physical properties of binderless bark particleboard made from Gelam bark waste and the improvement of those properties. In addition, the thermal insulation properties of the particleboard were determined. Four different temperatures $\left(140^{\circ} \mathrm{C}, 160^{\circ} \mathrm{C}, 180^{\circ} \mathrm{C}\right.$, and 200 ${ }^{\circ} \mathrm{C}$ ) were used to make single-layer binderless bark particleboard with a target density of less than or equal to $0.59 \mathrm{~g} / \mathrm{cm}^{3}$. Results revealed that the pressing temperature affected the mechanical properties (modulus of rupture, modulus of elasticity, and tensile strength perpendicular to panel surface), which increased as the temperature increased, and the physical properties (thickness swelling and water absorption), which decreased as the temperature increased. Based on the Tukey test, increasing the temperature from 180 to $200{ }^{\circ} \mathrm{C}$ did not significantly affect the mechanical or physical properties, except for the tensile strength perpendicular to panel surface. None of the mechanical properties met SNI standard 032105-2006 (2006); however, the $12 \%$ maximum thickness swelling requirement was met for binderless bark particleboard hot-pressed at 200 ${ }^{\circ} \mathrm{C}$. Binderless bark particleboard hot-pressed at $200^{\circ} \mathrm{C}$ had high water resistance, regardless of its low strength, and a thermal conductivity value of $0.14 \mathrm{~W} / \mathrm{m} \cdot \mathrm{K}$.
\end{abstract}

Keywords: Mechanical properties; Dimensional stability; Thermal conductivity; Self-bonding; Lignocellulosic material

Contact information: a: Postgraduate Program, Faculty of Agriculture, Brawijaya University, Malang 65145 Indonesia; $b$ : Department of forestry, Faculty of Agriculture, Palangka Raya University, Palangka Raya, Central Kalimantan 74874 Indonesia; c: Department of Soil Science, Faculty of Agriculture, Brawijaya University, Malang 65145 Indonesia; d: Department of Agricultural Engineering, Faculty of Agricultural Technology, Brawijaya University, Malang 65145 Indonesia; e: Department of Civil Engineering, Faculty of Engineering, Brawijaya University, Malang 65145 Indonesia; *Corresponding author: eochristy28@gmail.com

\section{INTRODUCTION}

Lignocellulosic materials from agricultural waste products, forestry residues, and other non-wood products can be used as alternative raw materials for the production of composite panels, e.g., particleboards and fiberboards. A similar trend is also apparent in the use of adhesive-free panel technology. These tendencies are driven by the scarcity of wood resources and the formaldehyde emissions associated with the production of particleboards (Wang et al. 2018). Formaldehyde emissions from formaldehyde-based adhesives are quite detrimental to human health, as they may lead to illness, e.g., leukemia 
(Golden 2011; Zhang and Lin 2016). Numerous studies have addressed this global problem. These studies encourage the production of binderless boards from waste generated in the production of rattan furniture (Ahmad et al. 2019), also from agricultural waste such as unripe coconut husks (Araújo Junior et al. 2018), wheat straw residues (Domínguez-Robles et al. 2020), rice husk (Ferrandez-Garcia et al. 2017), sunflower bark and flax shives (Mahieu et al. 2019), banana trunk waste (Nadhari et al. 2019), and almond residues (Ferrandez-Villena et al. 2019). There are also binderless boards made from other natural resources, i.e., Totora (Schoenoplectus californicus (C.A. Mey) Soják) stems (Hidalgo-Cordero et al. 2020) and Arundo donax L. rhizomes (Ferrandez-Villena et al. 2020).

Wood bark is a lignocellulosic-based forestry residue waste product that could be considered for the production of binderless particleboards (Romaní et al. 2020). Chen and Yan (2018) pointed out that bark is the outermost layer of a tree trunk. The primary chemical composition of tree bark is quite similar to wood, i.e., it consists of cellulose, hemicellulose, and lignins; however, tree bark is also rich in extractives such as tannins, suberins, rosins, etc. Chen and Yan (2018) also stated that tannins and lignins have adhesive properties. With regard to these two components, Chow $(1972,1975)$ argued that a high-density bark board can be made without synthetic resin, since both extractives and lignins, which are phenolic materials, can function as an adhesive and therefore may contribute to the self-bonding process of bark particles. Nitu et al. (2017) pointed out that the chemical composition of a lignocellulosic material is an important consideration and determines its suitability in the making of binderless composites.

In the case of manufacturing panels from tree bark without synthetic adhesives, the authors learned that high-temperature pressing is more favorable because a temperature higher than $180{ }^{\circ} \mathrm{C}$ will improve the physical and mechanical properties of the board. At that temperature (greater than $180^{\circ} \mathrm{C}$ ), thermal reactions, i.e., polymerization and partial degradation of the chemical components of the bark, will occur. The polymerization of the phenolic extractives and possibly lignins will produce a strong bond between the bark particles (Chow 1972, 1975). In addition, it should be noted that oven-dried samples comprised of wood and bark begin to soften at $180{ }^{\circ} \mathrm{C}$ (Chow and Pickles 1971). In regard to the parameters of binderless particleboard production via the hot-pressing process, Gupta et al. (2011) argued that the pressing temperature is one of the most important parameters in producing particleboards without synthetic resin (bark board), since the binding of wood bark particles without synthetic adhesive is believed to occur due to a thermal effect. Gupta et al. (2011) found that all the properties of the bark board made from beetle-infested lodgepole pine (Pinus contorta) bark drastically increased as the pressing temperature increased, from 170 to $230^{\circ} \mathrm{C}$. In the production of adhesive-free boards using other materials, Boon et al. (2013) maintained that the role of the pressing temperature in terms of improving the mechanical properties of binderless particleboards made from palm oil trunk is more important than any other parameters.

Gelam bark waste (GBW) is a lignocellulosic material, and Xiao et al. (2014) mentioned that the bark from the Melaleuca tree is rich in lignins. It is an abundant waste material, which is generated by peeling the bark off a Gelam log with a diameter of less than $10 \mathrm{~cm}$. The Gelam tree has multi-layered bark, and it is one of the Melaleuca species grown in Central Kalimantan. According to Sakasegawa et al. (2003), this tree is locally referred to as Gelam in Indonesia. Supriyati et al. (2015) mentioned that the Melaleuca species naturally and abundantly grows in Indonesian territory, especially in the peat 
swamp forests of Central and South Kalimantan, and along the southern coast of Sumatera. Usually, bark waste is simply burned, used as land filling, or thrown into the river, which obviously creates an environmental problem. Given the chemical content of GBW, the authors believe that it is suitable to proposing the use of GBW to produce a low-density binderless bark particleboard (BBP) via the hot-pressing process with the pressing temperature as a variable parameter. To the best of the authors' knowledge, there is only limited information on the making of binderless bark particleboards from Gelam bark waste. A previous study by Sato (2008) explored the possibility of producing high-density bark binderless boards from Melaleuca bark with the hot-pressing temperature at $180^{\circ} \mathrm{C}$. However, there is no information about the effect of the pressing temperature on lowdensity binderless bark particleboard properties made from Gelam bark using a highpressing temperature at $180{ }^{\circ} \mathrm{C}$ and $200{ }^{\circ} \mathrm{C}$ in the production of its. Therefore, this recent study investigates the effect of the pressing temperature on the mechanical and physical properties of BBP made from GBW. The mechanical and physical properties evaluated included the modulus of rupture (MoR), modulus of elasticity (MoE), tensile strength perpendicular to panel surface (TSPtPS), density, moisture content (MC), thickness swelling after $24 \mathrm{~h}$ of soaking (TS24h), and water absorption after $24 \mathrm{~h}$ of soaking (WA24h). Also, the chemical properties of the raw materials were determined by conventional chemical analysis. Furthermore, Fourier-transform infrared spectroscopy was used to observe any changes in the FTIR spectra between the raw material and the BBP, which were pressed at different temperatures. Observation via scanning electron microscopy equipped with energy-dispersive $\mathrm{X}$-ray analysis was also performed to study the microstructure and quality of the bonding was formed in the BBP. Besides, according to Lakreb et al. (2018) there has been growing interest in using bark particleboard as a thermal insulation material in recent years. As in studies by Pásztory et al. (2017) and Pásztory et al. (2019), the resulting bark particleboard has a low density, resulting in good thermal insulation properties. Regarding BBP, which also made with the low-density target. So that thermal insulation properties also need to be determined in view of its use as an insulating material.

\section{EXPERIMENTAL}

\section{Raw Materials}

Gelam (Melaleuca viridiflora Sol. ex Gaertn.) bark waste used in this study was obtained from Central Kalimantan, specifically from a local Gelam wood seller in the village of Garung, Jabiren Raya, in the Pulang Pisau Regency (location coordinates $114^{\circ} 12^{\prime} 29.99^{\prime \prime} \mathrm{E}$ and $\left.2^{\circ} 38^{\prime} 14.96^{\prime \prime} \mathrm{S}\right)$. The GBW was obtained by stripping Gelam wood logs with a diameter of less than $10 \mathrm{~cm}$ and an approximate thickness of $3.5 \mathrm{~mm}$. Both parts of the bark, i.e., inner and outer, were used in the study. The bark was manually cut using a machete to a length of approximately $1 \mathrm{~cm}$ to $4 \mathrm{~cm}$ (Fig. 1a), then air-dried for approximately three weeks until the moisture content decreased to the range $13 \%$ to $15 \%$. Afterward, these small pieces were mashed using a wood crusher, and the particles that passed through the 10 mesh sized filters were used to make the BBP (Fig. 1b). Finally, the particles were air-dried until the moisture content decreased to $5 \%$ to $7 \%$. The irregular shapes of the bark particles, which occurs in both the outer and inner barks, can be seen in Fig. 1c. 


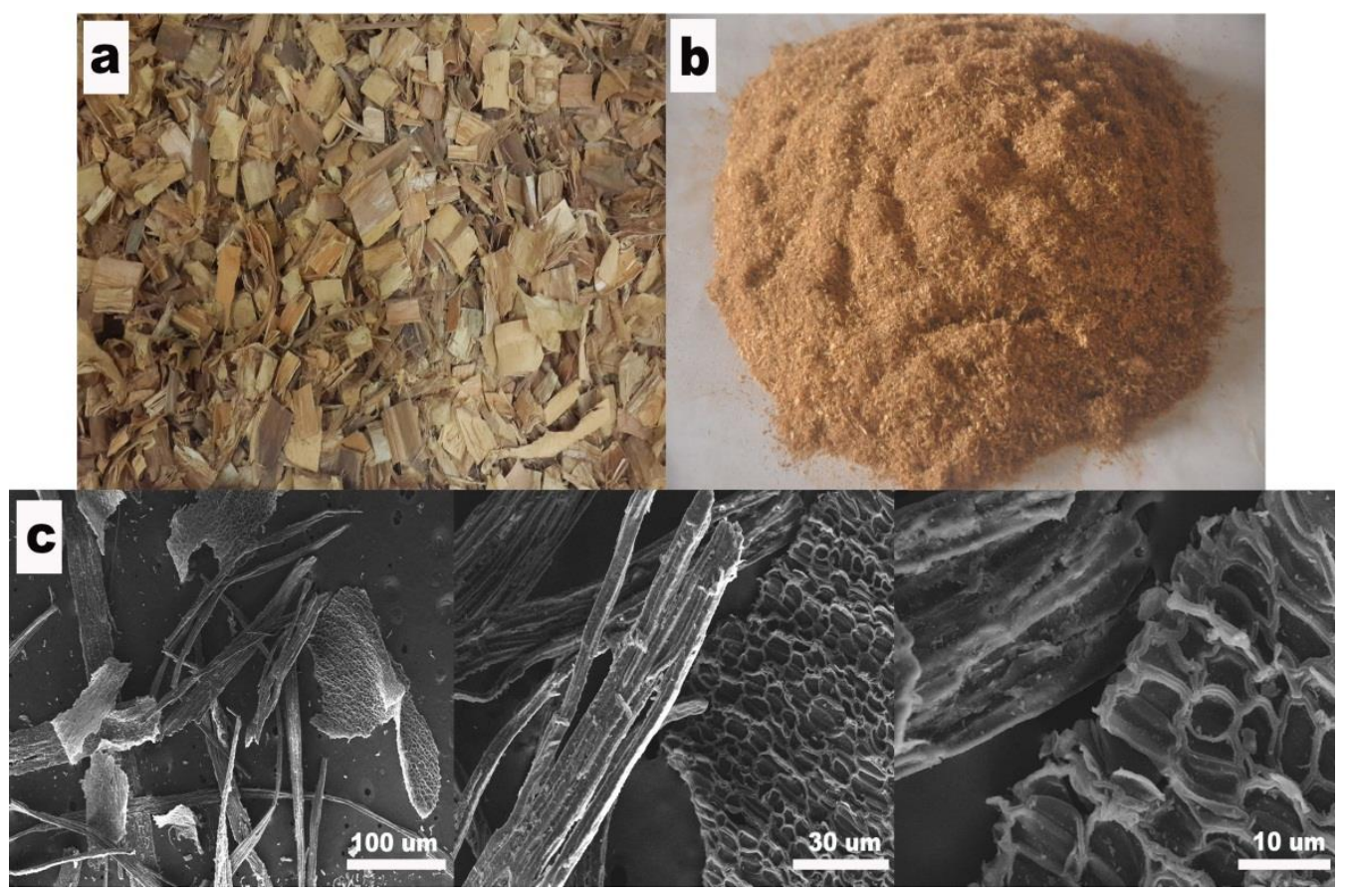

Fig. 1. Photograph of the barks: (a) small cut bark; (b) bark particles; and (c) SEM micrographs of the bark particles at different magnifications.

\section{Chemical Analysis of the Raw Materials}

The chemical content of the GBW was analyzed according to the following standards: SNI standard 8401:2017 (2017)/Identical with TAPPI standard T204cm-07 (Alcohol-benzene and dichloromethane Extractives), SNI standard 01-1305-1989 (1989) (Solubility in hot water), SNI standard 14-1838-1990 (1990) (Solubility in 1\% $\mathrm{NaOH}$ ), Wise methods (Wise 1946) (Holocellulose), ASTM standard D1103-60 (1977) ( $\alpha$ cellulose), SNI standard 0492-2008 (2008) (Klason Lignin), and SNI ISO standard 776:2010 (2010) (Ash). All chemical analyses were repeated three times.

\section{Manufacturing and Testing}

There are four types of BBP based on the pressing temperature used during manufacturing, i.e., the boards pressed at $140,160,180$, and $200{ }^{\circ} \mathrm{C}$ (five replicates for each temperature treatment), for a total of 20 single-layer boards measuring $300 \mathrm{~mm} \times 300$ $\mathrm{mm} \times 10 \mathrm{~mm}$ with a target density of less than or equal to $0.59 \mathrm{~g} / \mathrm{cm}^{3}$. To make the boards, $540 \mathrm{~g}$ of bark particles were first manually molded into a mat shape by placing and trampling it on a rectangular wooden forming box, whose base was covered with an aluminum sheet. A thickness bar was placed on top of the aluminum sheet, in the form of a wood frame measuring $300 \mathrm{~mm}$ long and $10 \mathrm{~mm}$ thick. The dimensions of the wooden forming box were $300 \mathrm{~mm} \times 300 \mathrm{~mm}$ with a height of $100 \mathrm{~mm}$. After the mat was molded, its upper surface was covered with another aluminum sheet (as shown in Fig. 2). Then the mat was cold-pressed for 5 min, followed by hot pressing at four different temperatures (for each temperature sample set) with a pressure of $30 \mathrm{~kg} / \mathrm{cm}^{2}$ for 20 min using a hydraulic hot press (Carver Laboratory Press, Carver Inc., Wabash, IN). To avoid blowing and blistering as well as ensuring the continuity of pressing the board with a hot-pressing machine, without turning off the tool, the board was immediately removed from the hotpressing machine and transferred into a clamp to be cooled for $24 \mathrm{~h}$, after which the clamp 
was removed. Then, the board was conditioned for two weeks via air-drying at a temperature of $25^{\circ} \mathrm{C}$ to $30{ }^{\circ} \mathrm{C}$ with a relative humidity of $60 \%$ to $65 \%$. Finally, the board was ready to be cut into a test sample.

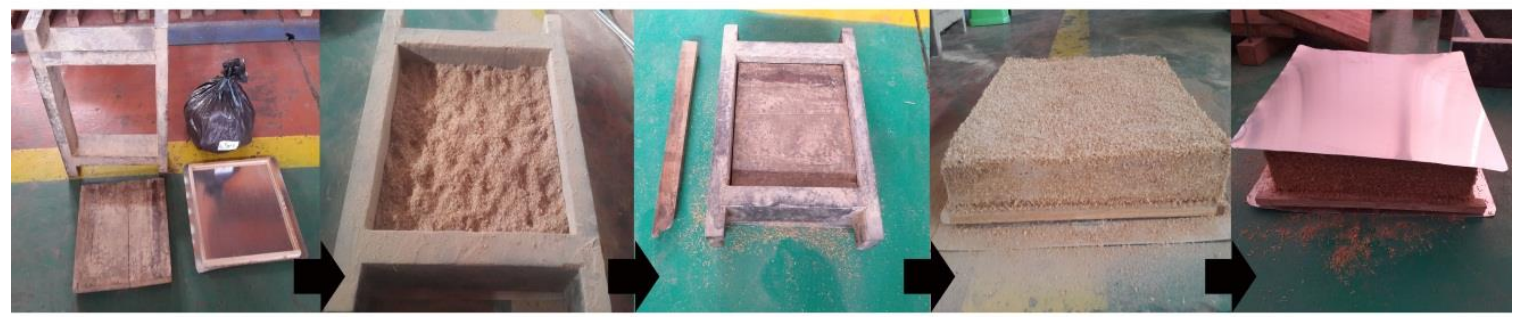

Fig. 2. The manual formation of a mat

Five replicate test samples for each physical and mechanical properties test were prepared for each pressing temperature. All tests were carried out according to SNI standard 03-2105-2006 (2006). The physical properties tests included determining the density, moisture content (MC), thickness swelling after $24 \mathrm{~h}$ of soaking (TS24h), and water absorption after $24 \mathrm{~h}$ of soaking (WA24h) of the boards. The SNI standard 03-21052006 (2006) does not set standards for the water absorption of particleboard. However, the water absorption needs to be tested to determine how resistant the boards were to water, particularly for exterior use.

For the density and MC tests, samples measuring $100 \mathrm{~mm}$ x $100 \mathrm{~mm}$ were prepared. For these two tests, the same samples were used, because the density test did not damage the samples. The density test was carried out under air-dry conditions. First, the sample was weighed, then its volume was calculated by measuring the average length and width of the boards from two different measurement points; the thickness of the boards was determined by measuring the average thickness from four measurement points. The density of the boards was obtained by dividing its weight by its volume. Meanwhile, the MC was calculated by subtracting the initial weight of the board from the final weight of the board after it was dried in an oven at $103{ }^{\circ} \mathrm{C} \pm 2{ }^{\circ} \mathrm{C}$ until it reached a constant weight.

The TS24h and WA24h values of the boards were determined using test samples measuring $50 \mathrm{~mm} \times 50 \mathrm{~mm}$. The tests were carried out by submerging the samples horizontally underwater at a temperature of $25^{\circ} \mathrm{C} \pm 1{ }^{\circ} \mathrm{C}$ for $24 \mathrm{~h}$. Before submerging the samples, the authors made a note of the initial weight and thickness of the samples. After soaking, the weight and thickness of the samples were remeasured. The measurement method for determining the thickness of the samples, before and after soaking, was taken at the same location, i.e., all four corners that were located $10 \mathrm{~mm}$ from its actual corners (at the point of intersection of the length and width measurement).

When testing the mechanical properties of the boards, i.e., its modulus of rupture $(\mathrm{MoR})$ and modulus of elasticity (MoE), samples were prepared that measured $200 \mathrm{~mm} \mathrm{x}$ $50 \mathrm{~mm}$, and the test was conducted using an Iber Test universal testing machine (Model MIB20AM, Madrid, Spain) under dry conditions. The test samples were placed horizontally on the two supports (the length of the support span was $150 \mathrm{~mm}$ ), and the load was applied at the center of the samples with a loading speed of $10 \mathrm{~mm} /$ minute. The deflection was recorded, and the load application was continued until it reached its maximum load. In principle, the MoR refers to the ability of the adhesive-free particleboards to withstand a centrally applied load in a dry state. The tensile strength perpendicular to panel surface (TSPtPS) test, which is also known as the internal bonding 
strength (IB) test, is intended to measure the strength of adhesive-free particleboard in terms of sustaining an upright tensile load on its surface. The testing was carried out on a test sample that measured $50 \mathrm{~mm}$ x $50 \mathrm{~mm}$. First, the length and width of the sample were measured and recorded. Then the sample was glued to two iron blocks and left to dry for $24 \mathrm{~h}$. Afterward, the sample was pulled vertically with a loading speed of $2 \mathrm{~mm} / \mathrm{min}$.

Three pieces of BBPs that were pressed at $200{ }^{\circ} \mathrm{C}$ were selected for the thermal conductivity tests $(\lambda)$ at room temperature using a Kemtherm QTM-D3 thermal conductivity meter equipped with QTM PD3 probe (Kyoto Electronics Manufacturing Ltd, Kyoto, Japan). The basic principles of testing used the transient hot-wire method. Samples measuring $145 \mathrm{~mm}$ x $55 \mathrm{~mm}$ were prepared for the test. The probe was connected to the measuring device (the cable is connected to a 220 -volt power supply), and the device was then heated for $30 \mathrm{~min}$. The value of the heater current was $1 \mathrm{~A}^{2}$, which was based on the conductivity of the sample being tested. The value of the constant was adjusted to the value on the probe constant table; the probe was then placed on top of the sample. After a count down from 60 to $0 \mathrm{~s}$, the thermal conductivity value would be shown on the digital display.

The data collected from testing the mechanical and physical properties were statistically analyzed using a single-factor analysis of variance (ANOVA) in Microsoft Excel for Windows, followed by Tukey's (HSD) post hoc test with $\alpha$ equal to 0.05.

\section{Fourier Transform Infrared Spectroscopy (FTIR)}

The samples used in the analysis were the raw materials as well as the boards that were hot pressed at four different pressing temperatures (these samples were previously used in the bending strength tests). The FTIR analysis was carried out with a Shimadzu IR Prestige-21 Infrared spectrophotometer (Shimadzu Corporation, Kyoto, Japan). The test samples were prepared in the form of KBr-pellets, and then the IR spectra were taken within the range of 4000 to $500 \mathrm{~cm}^{-1}$ and recorded with $40 \mathrm{scans}$ at a resolution equal to $4.0 \mathrm{~cm}^{-1}$.

\section{Scanning Electron Microscopy (SEM)}

For this analysis, the BBP samples were cut into parallel-sections and crosssections. Then, a microstructure observation was performed using a Carl-Zeiss (Evo MA 10, Cambridge, United Kingdom) scanning electron microscope (SEM), equipped with a Bruker (Quantax, Bruker Nano GmbH, Berlin, Germany) energy dispersive X-ray spectroscopy (EDX) detector, which was operated using an accelerated voltage of $20 \mathrm{kV}$. Before observation, the samples were coated with gold-palladium for 60s using an Emitech sputter coater (SC7620, Quorum Technologies Ltd, Lewes, United Kingdom). The SEM micrographs were taken at $60 \mathrm{x}, 300 \mathrm{x}$, and $1000 \mathrm{x}$ magnifications for each surface and cross-section. The EDX analysis for the cross-sections was taken at $300 \mathrm{x}$ magnifications.

\section{RESULTS AND DISCUSSION}

All BBPs, i.e., the samples made at different pressing temperatures, were made without delamination. The board pressed at a temperature of $200{ }^{\circ} \mathrm{C}$ had a smooth surface. Moreover, all the boards pressed at different pressing temperatures showed varying surface colors, ranging from light brown to dark brown with respect to the lowest temperature to the highest (as shown in Fig. 3). The material also emitted a distinctive odor. Similar results were also noticeable in the binderless boards made using the following raw materials: 
bagasse (Panyakaew and Fotios 2011), palm oil trunk (Boon et al. 2013), unripe coconut husk (Araújo Junior et al. 2018), wheat straw (Wang et al. 2019), soybean straw (Song et al. 2020), jute stick (Nitu et al. 2020), and densified wood (Shi et al. 2020); this could be the result of the modification of the chemical components that occurs during the heat treatment (Panyakaew and Fotios 2011; Wang et al. 2019). The presence of hemicellulose degradation and extractive movement may be the cause of the darkening of the color (Shi et al. 2020). Furthermore, Pintiaux et al. (2015) mentioned that the color change in the specimen was a sign of degradation, as reported by Araújo Junior et al. (2018) biomass components, namely hemicellulose, decompose at temperatures of $170{ }^{\circ} \mathrm{C}$ or higher, while cellulose decomposes at $200{ }^{\circ} \mathrm{C}$ or higher. Meanwhile, lignin decomposes more slowly in the range of 200 to $500^{\circ} \mathrm{C}$.
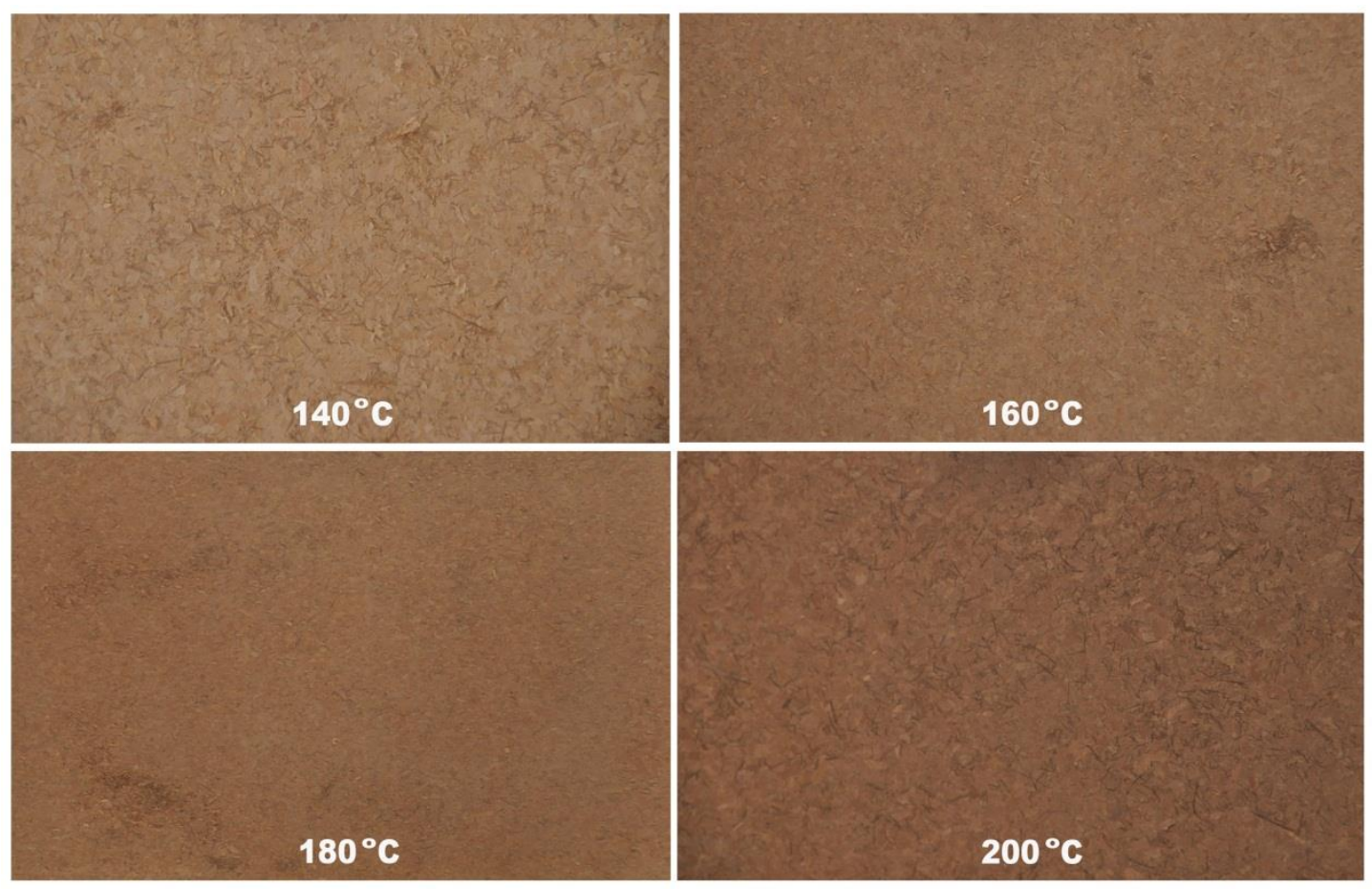

Fig. 3. Appearance of the BBP surface at various pressing temperature

\section{Chemical Properties of the Raw Material}

The results of the GBW chemical analyses are shown in Tables 1 and 2. As can be seen in Table 1, the average holocellulose value for GBW was 78.8\%, which is higher than the holocellulose values of woods from Borneo (Pettersen 1984). The GBW holocellulose value was also relatively higher than the holocellulose value found in a study by Ozgenc et al. (2017). The high holocellulose content of the bark is probably the result of the bark being peeled from the trunk using a commercial log-peeling machine. Tree bark stripped with commercial log-peeling machines often contains a large amount of actual wood, with less lignins and extractives and more cellulose than only bark (Geng et al. 2006). This explanation seems plausible because it is quite likely that wood could have been ripped away along with the bark when the bark was stripped from the trunk; this is also true for the Gelam bark stripped in the traditional way using a machete. Another explanation for this is the fact that holocellulose still contains lignin residues (Santana and Okino 2007). As shown in Table 1, the holocellulose content is corrected by lignin residues (Harun and 
Labosky 2007) and showed a lower value than GBW. Meanwhile, the average alphacellulose value of GBW was lower than the alpha-cellulose value of the woods from Borneo. The ash content of GBW (1.23\%) is not high compared to the ash content of shagbark hickory (7.8\%) but was higher than that of Melaleuca sp. wood (1.04\%).

Table 1. The Main Components and the Ash Content of GBW Compared with Data from Literature Reviews on Wood and Other Tree Barks

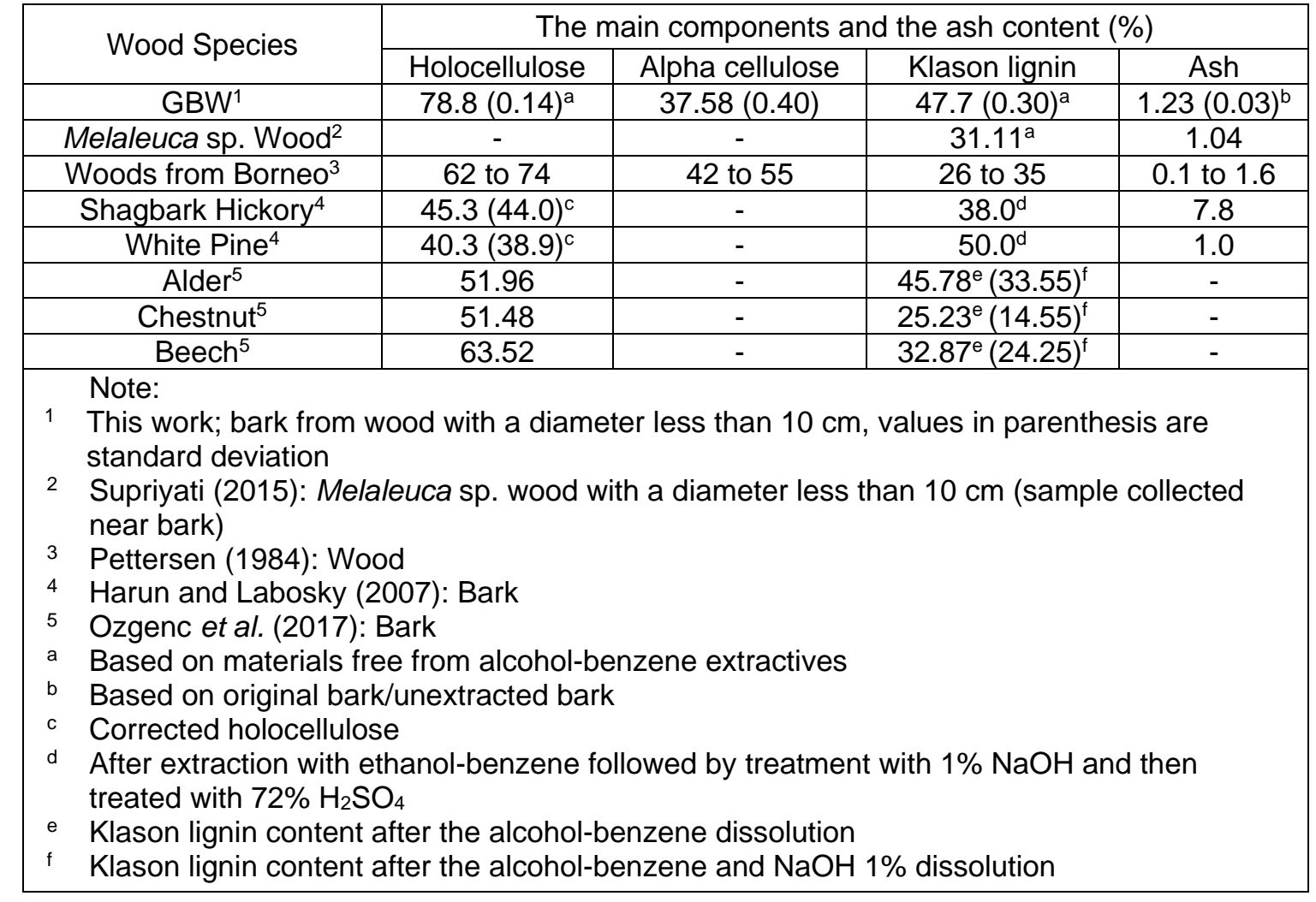

The Klason lignin content of GBW (47.7\%) is lower than the Klason lignin content of white pine bark but higher than the Klason lignin content of shagbark hickory (Harun and Labosky 2007). In addition, the Klason lignin content of GBW is higher than the Klason lignin contents of alder, chestnut, and beech bark, after an alcohol-benzene only dissolution and an alcohol-benzene and $\mathrm{NaOH} 1 \%$ dissolution (Ozgenc et al. 2017). The Klason lignin content of GBW is also higher than the Klason lignin content of Melaleuca sp. wood. From these results, the authors concluded that the Klason lignin content of GBW was high. However, Santana and Okino (2007) claimed that the method for determining lignin content has some flaws, which may give the impression of a higher lignin content than the actual figure (most common) or reduce it (rare). In the case of tree bark, Dou et al. (2018) argued that Klason lignins possibly also include other components other than lignins, even though the samples have been extracted in succession with several different solvents using commonly used methods. These components include condensed and hydrolysable tannins, and suberins that give the impression of a higher lignin content instead of the actual value (Harkin and Rowe 1971; Harun and Labosky 2007; Rowell et al. 2012). For the results of misleading from standard lignin analysis, Harkin and Rowe (1971) mark the word "lignin" which consists of a mixture of true lignin and suberized phlobaphene ranging from 40 to $50 \%$ for hardwood bark. 
Table 2. Extractive Contents/solubility of GBW Compared with Data from Literature Reviews on Wood and Other Tree Barks

\begin{tabular}{|c|c|c|c|c|}
\hline \multirow[b]{2}{*}{ Wood Species } & \multicolumn{4}{|c|}{ Extractives/solubility (\%) } \\
\hline & $\begin{array}{c}\text { Alcohol-benzene } \\
\text { extractives }\end{array}$ & $\begin{array}{c}\text { Solubility in } \\
\text { Hot water }\end{array}$ & $\begin{array}{c}\text { Dichloromethane } \\
\text { extractives }\end{array}$ & $\begin{array}{c}\text { Solubility in } \\
1 \% \mathrm{NaOH}\end{array}$ \\
\hline GBW $^{1}$ & $7.78(0.43)$ & $4.07(0.13)^{\mathrm{a}}$ & $7.03(0.02)$ & $32.65(0.25)$ \\
\hline Melaleuca sp. Wood² & 4.28 & 4.01 & - & 15.94 \\
\hline Woods from Borneo 3 & 1 to 14 & 2 to 13 & - & - \\
\hline Shagbark Hickory ${ }^{4}$ & 11.0 & - & - & - \\
\hline White Pine ${ }^{4}$ & 5.7 & - & - & - \\
\hline Alder $^{5}$ & 9.23 & - & - & 37.63 \\
\hline Chestnut $^{5}$ & 15.20 & - & - & 46.13 \\
\hline Beech $^{5}$ & 5.50 & - & - & 26.93 \\
\hline $\begin{array}{ll} & \text { Note: } \\
1 & \text { This work; bark from } \\
& \text { standard deviation } \\
2 & \text { Supriyati (2015): } M \\
& \text { near bark) } \\
3 & \text { Pettersen (1984): } \\
4 & \text { Harun and Labosky } \\
5 & \text { Ozgenc et al. (2017 } \\
\text { a } & \text { Solubility in hot wat } \\
& \text { treatment }\end{array}$ & $\begin{array}{l}\text { vood with a diame } \\
\text { leuca sp. wood wi } \\
\text { od } \\
\text { (007): Bark } \\
\text { Bark } \\
\text { performed after th }\end{array}$ & $\begin{array}{l}\text { less than } 10 \\
\text { a diameter le }\end{array}$ & $\begin{array}{l}\mathrm{n} \text {, values in parent } \\
\text { than } 10 \mathrm{~cm} \text { (samp }\end{array}$ & $\begin{array}{l}\text { sis are } \\
\text { collected }\end{array}$ \\
\hline
\end{tabular}

A comparison of the extractive contents/solubility of GBW is given in Table 2 . The alcohol-benzene extractives (7.78\%) and $1 \% \mathrm{NaOH}(32.65 \%)$ solutions of GBW were higher than the alcohol-benzene extractives, and the solubility values of Melaleuca sp. wood, its solubility value in hot water did not differ by much. When compared to the alcohol-benzene extractives (1\% to $14 \%$ ) and the solubility in hot water (2\% to $13 \%$ ) of the woods from Borneo, the solubility value of GBW was still within range. The dichloromethane extractives $(7.03 \%)$ of GBW were slightly lower than the alcoholbenzene extractives. In contrast, when compared to bark from other wood species, the alcohol-benzene extractives of GBW were higher than white pine $(5.7 \%)$ and beech (5.50\%), but lower than shagbark hickory (11.0\%), alder (9.23\%), and chestnut (15.2\%). Likewise, the solubility value of GBW in $1 \% \mathrm{NaOH}$ was lower than alder (37.6\%) and chestnut (46.1\%). However, the Klason lignin, extractives, and ash contents of GBW were higher than the Melaleuca sp. Wood values. As stated by Sakai (2000), in general, wood bark contains more extractives than the wood sampled from the same tree. Still, the results of the chemical analysis label GBW as a lignocellulosic material, and its primary contents are holocelluloses and lignins.

The conventional chemical analysis of GBW in Table 1 revealed there was an overestimation of holocellulose and Klason lignin content, which may be due to contamination. This can happen since Klason lignin was determined on the bark extracted only with alcohol-benzene without being followed by extraction with hot water and $1 \%$ $\mathrm{NaOH}$. So, possibly phenolic compounds (such as tannins, phenolic acids) and suberin remain in the bark samples. Those compounds potentially function as a contaminant in Klason lignin. Since phenolic components dissolve in sulfuric acid, causing the lignin content in tree barks increase (Ozgenc et al. 2017). It also is mentioned by Gonultas and Ucar (2013) and Gonultas and Candan (2018) that phenolic compounds, such as tannins, 
could be condensed and remain with lignin in acidic conditions, which contributes to the overestimation of lignin content. Concerning suberin, as evidenced by Krogell et al. (2012), TMAH-Pyr-GCMS analysis has shown that suberin detected in Klason lignin residues from hexane and acetone-water pre-extracted Norway spruce bark. Previous work by Ozgenc et al. (2017) has indicated that lignin determined by Klason analysis in bark samples previously extracted with alcohol-benzene alone tends to be overestimated compared to lignin determined in bark samples that were extracted successively with alcohol-benzene and $1 \% \mathrm{NaOH}$. Likewise, for holocellulose determination, when a polymeric compound such as suberin is likely to remain in the bark sample after alcoholbenzene extraction, it would interfere with this holocellulose analysis method. Suberin tends to limit the access of delignification reagents to lignin in the bark (Rowell et al. 2012). Therefore, it is not feasible to obtain relatively pure holocellulose because it will likely contain a considerable amount of lignin. To overcome waxlike material, Harun and Labosky (2007) proposed that the alcohol-benzene extracted bark should be followed by treatment with $1 \%$ anhydrous $\mathrm{EtOH} / \mathrm{KOH}$ to remove waxlike materials. This means that the conventional analytical procedures used for wood are failing or inadequate for bark. However, relating with the high yield of holocellulose obtained in this study, it does not dismiss the possibility that, as previously stated, the presence of wood which is also peeled off when peeling the bark, also contributes to a higher holocellulose content. Besides, the bark contains quite a lot of fibers, although they are shorter than wood fibers.

However, indications of a high "lignin" and extractives content can be an essential ingredient in the production of BBP because, as phenolic materials, they can function as a natural adhesive. This refers to previous studies (Chow 1972, 1975; Gupta et al. 2011) that examined the effects of the pressing temperature on the properties of boards made without adhesive, wherein the possible polymerization and softening of these chemical components contribute to the self-bonding of bark particles at high-pressing temperatures.

Chow (1972) and Chow (1975) made bark boards from the bark of Douglas-fir (Pseudotsuga menziesii Mirb. Franco) without synthetic adhesive, using the hot-pressing method with a pressing temperature ranging from 200 to $300{ }^{\circ} \mathrm{C}$ and found that within this temperature range, the polymerization of extractives and lignins plays a role in the selfbonding of the bark particles. Furthermore, the studies by Chow (1972) and Chow (1975) also show that when boards are pressed at high temperatures (200 to $\left.300{ }^{\circ} \mathrm{C}\right)$ under an appropriate time-temperature schedule, they will yield mechanical and physical properties that are similar to bark boards made using $4.5 \%$ phenol-formaldehyde. Additionally, when boards are pressed at high temperatures, a certain amount of moisture is released, which is probably the result of condensation and dehydration of the chemical components of the bark. This method of board making, based on a study by Chow and Pickles (1971), found that oven-dried Douglas-fir and red alder bark begin to soften at a temperature of $180{ }^{\circ} \mathrm{C}$, while some minor additional softening occurring at $280{ }^{\circ} \mathrm{C}$, i.e., when moisture condensation is released. When a material a moisture content of greater than $10 \%$, softening begins to occur at $160{ }^{\circ} \mathrm{C}$. Afterward, it is postulated that the thermal softening of moistened bark that occurs at a temperature below $200{ }^{\circ} \mathrm{C}$ is primarily associated with plasticization, which only occurs in the amorphous region. Meanwhile, at temperatures higher than $180^{\circ} \mathrm{C}$, the thermal reaction of the bark is associated with the polymerization and partial degradation of various components of the bark, where the polymerization expects to be more advantageous for the dimensional stability, water resistance, and strength properties of the bark boards. Following the same pathway, Gupta et al. (2011) 
found that bark boards manufactured from beetle-infested lodgepole pine bark without synthetic resins could be bonded through polymerization of the extractives and lignins, and softening at higher temperatures (greater than $200{ }^{\circ} \mathrm{C}$ ). Another study by Hashim et al. (2011) showed that a low pressing temperature $\left(180{ }^{\circ} \mathrm{C}\right)$ is not sufficient for the plasticization of palm oil bark particles to occur when making particleboards without adhesive, considering that the glass transition values of lignins, cellulose, and hemicellulose in a dry state are 200,220 , and $170{ }^{\circ} \mathrm{C}$, respectively. Gao et al. (2011) described the process of manufacturing homogeneous binderless bark panels from refined black spruce bark with pressing temperatures in the range of 200 to $260{ }^{\circ} \mathrm{C}$ as well as from the ground bark particles with a pressing temperature of $260^{\circ} \mathrm{C}$. Gao et al. (2011) found that a higher pressing temperature is more favorable for in-situ transformation, degradation, crosslinking, polymerization, and bark thermosetting process, i.e., more bark mass will be degraded.

In the current study, the authors decided to make a board using a pressing temperature no higher than $200{ }^{\circ} \mathrm{C}$ for $20 \mathrm{~min}$, because when the authors attempted to make a board at a temperature higher than $200{ }^{\circ} \mathrm{C}$ for $20 \mathrm{~min}$, the process resulted in a partially scorched surface of the board.

\section{FTIR}

To get an overview of any changes in the chemical structure between the raw material and BBP pressed at different temperatures, FTIR analysis was carried out. The collected infrared spectra are shown in Fig. 4. After overlaying the spectra, changes only occurred at five absorption points, i.e., 3338, 1718, 1508, 1234, and $1041 \mathrm{~cm}^{-1}$. The absorption region at the $3400 \mathrm{~cm}^{-1}$ is the absorption of the hydroxyl group $(\mathrm{OH})$. There was a decrease in the absorption intensity of the hydroxyl group as the temperature was increased, which presumably was caused by the loss of $\mathrm{OH}$ due to the hot-pressing process. This process is closely related to the high hydrophobicity of the hot-pressed board (Araújo Junior et al. 2018). The absorption at the $1718 \mathrm{~cm}^{-1}$, which was detected in the BBP, may be produced by the acetyl polysaccharides group. Jumhuri et al. (2014) stated that the absorption region at the $1736 \mathrm{~cm}^{-1}$ not only indicates the presence of carboxylate groups, but also indicates the presence of $\mathrm{C}=\mathrm{O}$ groups (acetyl polysaccharide group), which likely originated from hemicellulose. The rising temperature leads to a degradation of hemicellulose, which is marked by a decline in the absorption intensity as the temperature rises. The absorption at approximately 1505 to $1512 \mathrm{~cm}^{-1}$ originates from the aromatic unit of lignins $(\mathrm{C}=\mathrm{C})$ (Widyorini et al. 2016), the absorption at 1508 and $1510 \mathrm{~cm}^{-1}$ are associated with lignins (Ozgenc et al. 2017), and absorption at the $1500 \mathrm{~cm}^{-1}$ is characteristic of lignin absorption of binderless fiberboard made from wheat straws (Wang et al. 2018). In addition, the absorption at approximately $1200 \mathrm{~cm}^{-1}$ originates from a lignin derivative (Okuda et al. 2006). There is a change in the absorption peak at approximately 1508 and $1200 \mathrm{~cm}^{-1}$, along with the increase in pressing temperature. The higher the pressing temperature, the lower the absorption intensity at the $1508 \mathrm{~cm}^{-1}$, which indicated that lignin degradation occurred. The absorption at the $1041 \mathrm{~cm}^{-1}$ originates from the bonding of C-O-C hemiacetal polysaccharides (Liao et al. 2016), and the present study also showed a change in that group due to the increase in pressing temperature. The C-O-C bond on the BBP is believed to originate from cellulose and hemicellulose. The decrease in absorption intensity at the $1041 \mathrm{~cm}^{-1}$, along with the rising pressing temperature, points to hemicellulose degradation. 


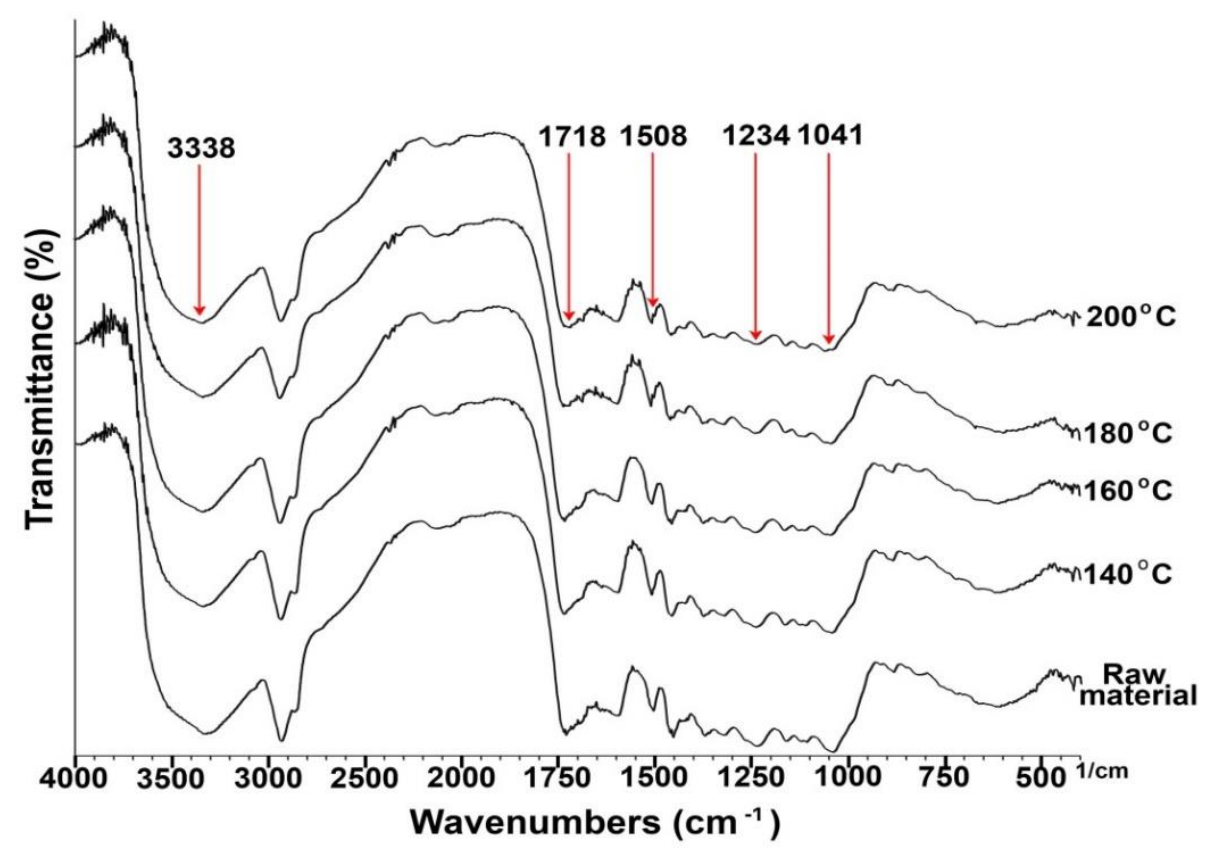

Fig. 4. The FTIR spectra of the GBW and BBP at different pressing temperatures

\section{SEM-EDX}

The SEM micrographs of the surfaces of the BBPs manufactured with four different temperature treatments are shown in Fig. 5. The BBPs pressed at temperatures of 140 and $160{ }^{\circ} \mathrm{C}$, still have many loosely interlocked particles, which results in a rough surface (as shown in Figs. 5a and 5b). The compressed particles are from the phloem and rhytidome, which are fibers from the phloem tissues/secondary phloem and periderm that are part of the rhytidome (Chiang and Wang 1984). The boards that were pressed at a temperature of $180{ }^{\circ} \mathrm{C}$ had a somewhat smooth surface (Fig. 5c) and had slightly tighter interlocking particles than the boards treated at $160{ }^{\circ} \mathrm{C}$, which indicated that softening had begun to occur. The boards treated at a temperature of $200{ }^{\circ} \mathrm{C}$ (Fig. 5d) show more compact and tightly interlocked particles, which produces a smooth surface and indicated the possibility of the occurrence of extractive polymerization and possibly lignins at a temperature that causes softening (Chow 1972). At a temperature of $200{ }^{\circ} \mathrm{C}$, it is visible that the lignins were already flowing and partially coating the bark particles surface on the board surface. This phenomenon was similar to the results observed by Araújo Junior et al. (2018), who analyzed the SEM micrograph of binderless fiberboards made from unripe coconut husk pressed at a temperature $220^{\circ} \mathrm{C}$. Araújo Junior et al. (2018) argued that the smooth surface of the panel was the result of the presence of lignins on the outside of the fibers, which increased under the high-pressing temperature, causing the lignins to flow as a layer of ink. The results of the SEM micrographs of the cross-sections of the four BBPs that were treated at four different pressing temperatures are shown in Fig. 6. They were consistent with the SEM micrographs of the surfaces of BBPs, wherein a higher pressing temperature led to a denser packing of the boards. In Figs. $6 a$ and $6 b$, there are more voids and gaps, which indicated poor bonding between the particles. However, the BBPs that were pressed at a temperature of 180 and $200{ }^{\circ} \mathrm{C}$ (Figs. 6c and 6d) showed almost no void spaces and tended to have a smoother texture. There appeared to be good contact between the particle surfaces. 


\section{bioresources.com}

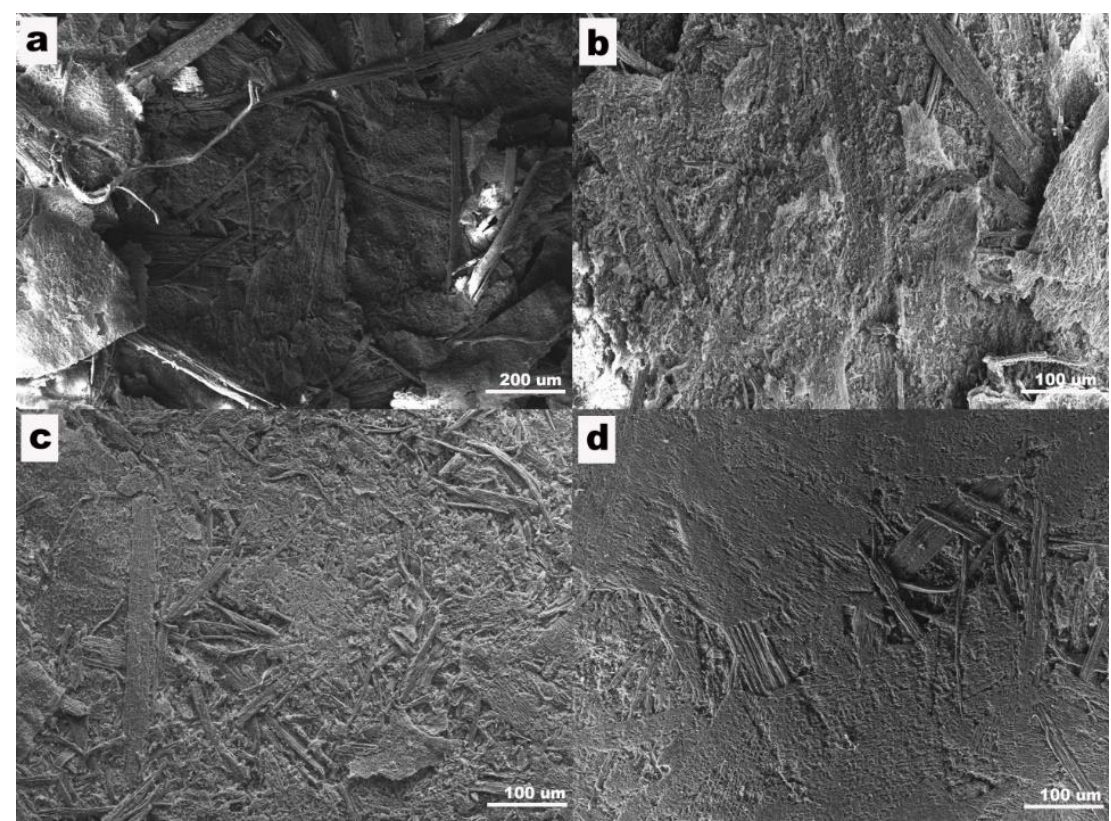

Fig. 5. The SEM micrographs of the BBPs surfaces pressed at different temperatures: (a) $140{ }^{\circ} \mathrm{C}$; (b) $160^{\circ} \mathrm{C}$; (c) $180^{\circ} \mathrm{C}$; (d) $200^{\circ} \mathrm{C}$

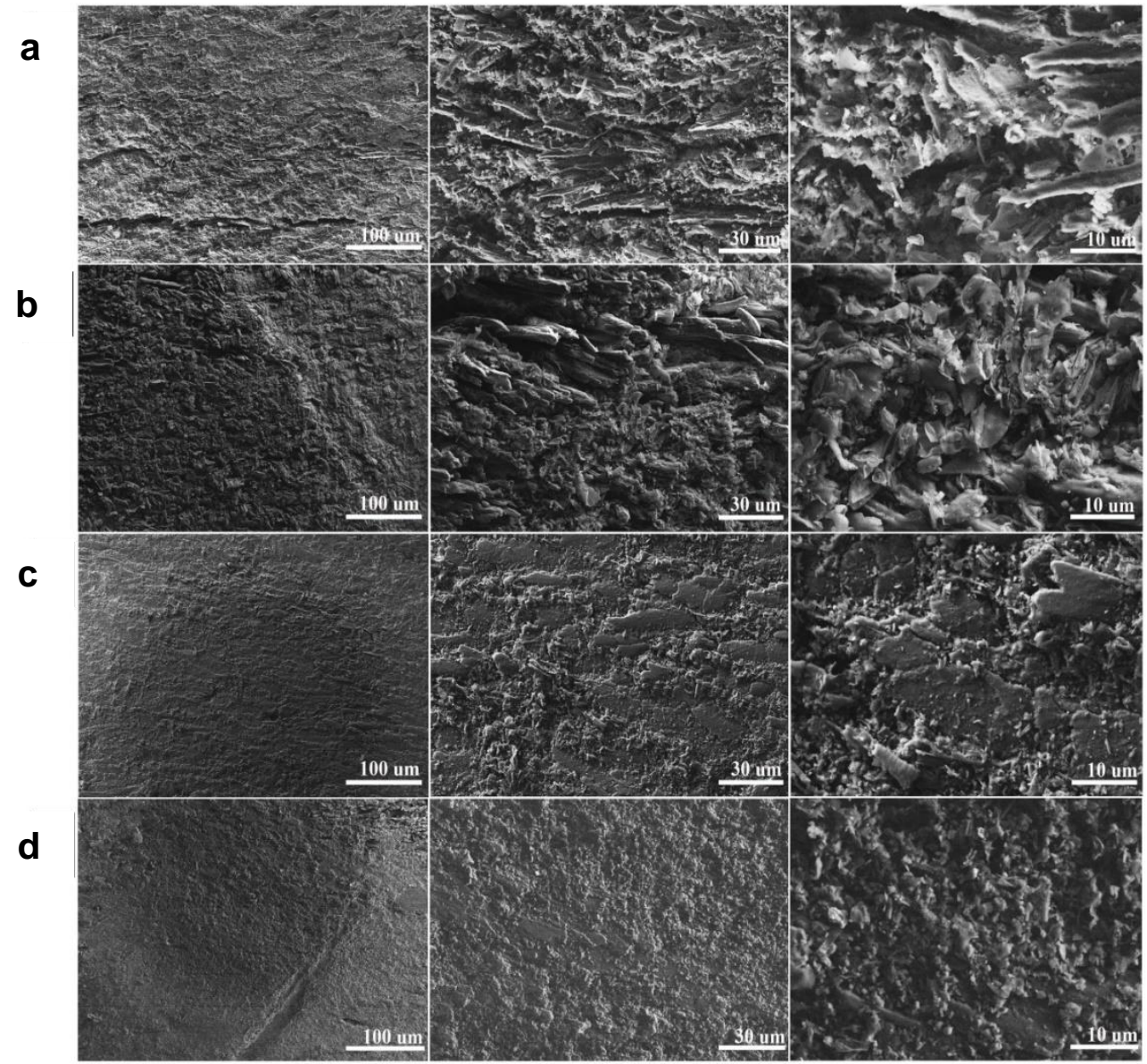

Fig. 6. The SEM micrographs of the cross-sections of BBPs pressed at different pressing temperatures: (a) $140{ }^{\circ} \mathrm{C}$; (b) $160^{\circ} \mathrm{C}$; (c) $180^{\circ} \mathrm{C}$; (d) $200^{\circ} \mathrm{C}$ (all four temperatures are shown at $60 \times, 300 \mathrm{x}$, and $1000 \mathrm{x}$ magnifications) 
The EDX analysis revealed that all BBPs that were pressed at four different temperatures had two major elements, i.e., carbon and oxygen, which occurred in a high percentage based on weight (Fig. 7). Significant differences were found in the inorganic elements when the BBP was pressed at a temperature of $140{ }^{\circ} \mathrm{C}$. The material contained a small amount of these elements (in descending order): chlorine was greater than calcium, which was greater than potassium. The BBP pressed at a temperature of $160{ }^{\circ} \mathrm{C}$ only contained chlorine, while the BBP pressed at a temperature of 180 and $200{ }^{\circ} \mathrm{C}$ contained no major or minor minerals. The EDX analysis of wood fibers in a study by Dang et al. (2018) also detected the presence of carbon and oxygen as major elements. This shows that these major elements are related to lignocellulosic materials. Additionally, there were no heavy metal elements detected. All the chemical elements found in BBP pressed at $140{ }^{\circ} \mathrm{C}$ were the same as those found by Sutrisno et al. (2015) in bio-based nanomaterial from Jabon wood bark.

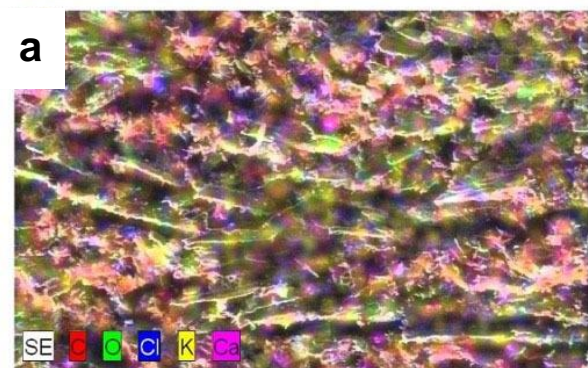

\begin{tabular}{|c|c|c|c|c|}
\hline 1 & AN & Series C & $\begin{array}{c}\text { norm. C } \\
\text { [wt. } \% \text { o }\end{array}$ & $\begin{array}{l}\text { Atom. C } \\
\left.\text { [at. } \frac{\circ}{b}\right]\end{array}$ \\
\hline C & 6 & K-series & 53.01 & 60.36 \\
\hline 0 & 8 & K-series & 45.90 & 39.24 \\
\hline $\mathrm{Cl}$ & 17 & K-series & 0.49 & 0.19 \\
\hline $\mathrm{Ca}$ & 20 & K-series & 0.34 & 0.12 \\
\hline $\mathrm{K}$ & 19 & K-series & 0.26 & 0.09 \\
\hline & & 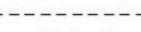 & & \\
\hline & & Total: & 100.00 & 100.0 \\
\hline
\end{tabular}
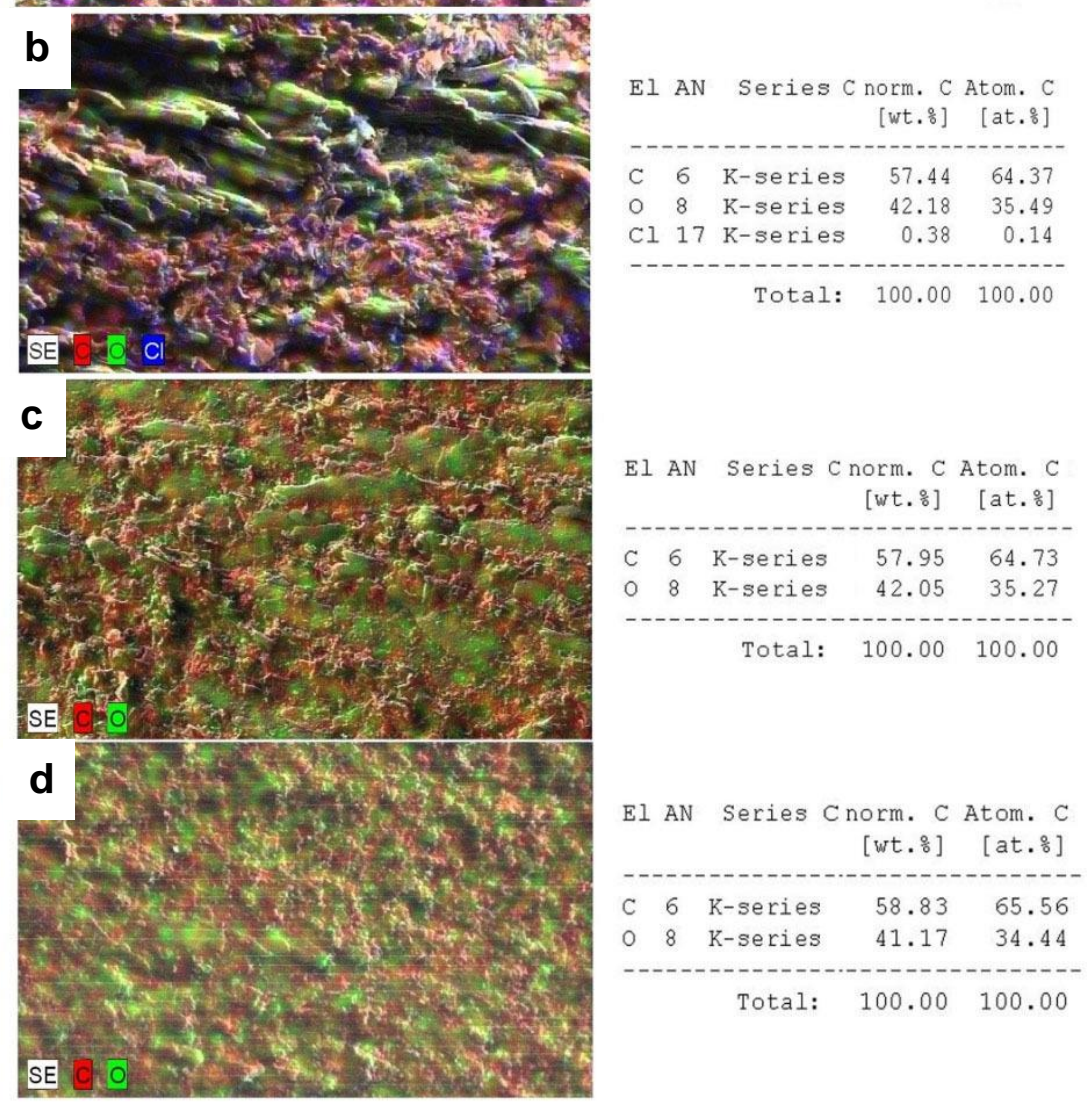

Fig. 7. The EDX mapping images of the cross-sections of BBPs pressed at different pressing temperatures: (a) $140{ }^{\circ} \mathrm{C}$; (b) $160^{\circ} \mathrm{C}$; (c) $180^{\circ} \mathrm{C}$; (d) $200^{\circ} \mathrm{C}$ (at a magnification of $300 \mathrm{x}$ ) 


\section{Mechanical Properties}

Figure 8 shows the average values of the MoR, MoE, and TSPtPS of the BBPs made with different pressing temperatures. All the mechanical properties of the BBPs were significantly affected by the hot-pressing temperature treatments (ANOVA p-value was less than 0.01). In general, the MoR, MoE, and TSPtPS values tended to increase as the pressing temperature increased. The average MoR, MoE, and TSPtPS values ranged from 15.0 to $40.5 \mathrm{~kg} / \mathrm{cm}^{2}, 2070$ to $7730 \mathrm{~kg} / \mathrm{cm}^{2}$, and 0.08 to $0.63 \mathrm{~kg} / \mathrm{cm}^{2}$, respectively. Based on the Tukey's test, it was found that the highest MoR value (from the $200{ }^{\circ} \mathrm{C}$ treatment) was significantly different from the MoR values of the 140 and $160{ }^{\circ} \mathrm{C}$ treatments; however, it was not significantly different from the $180{ }^{\circ} \mathrm{C}$ treatment.
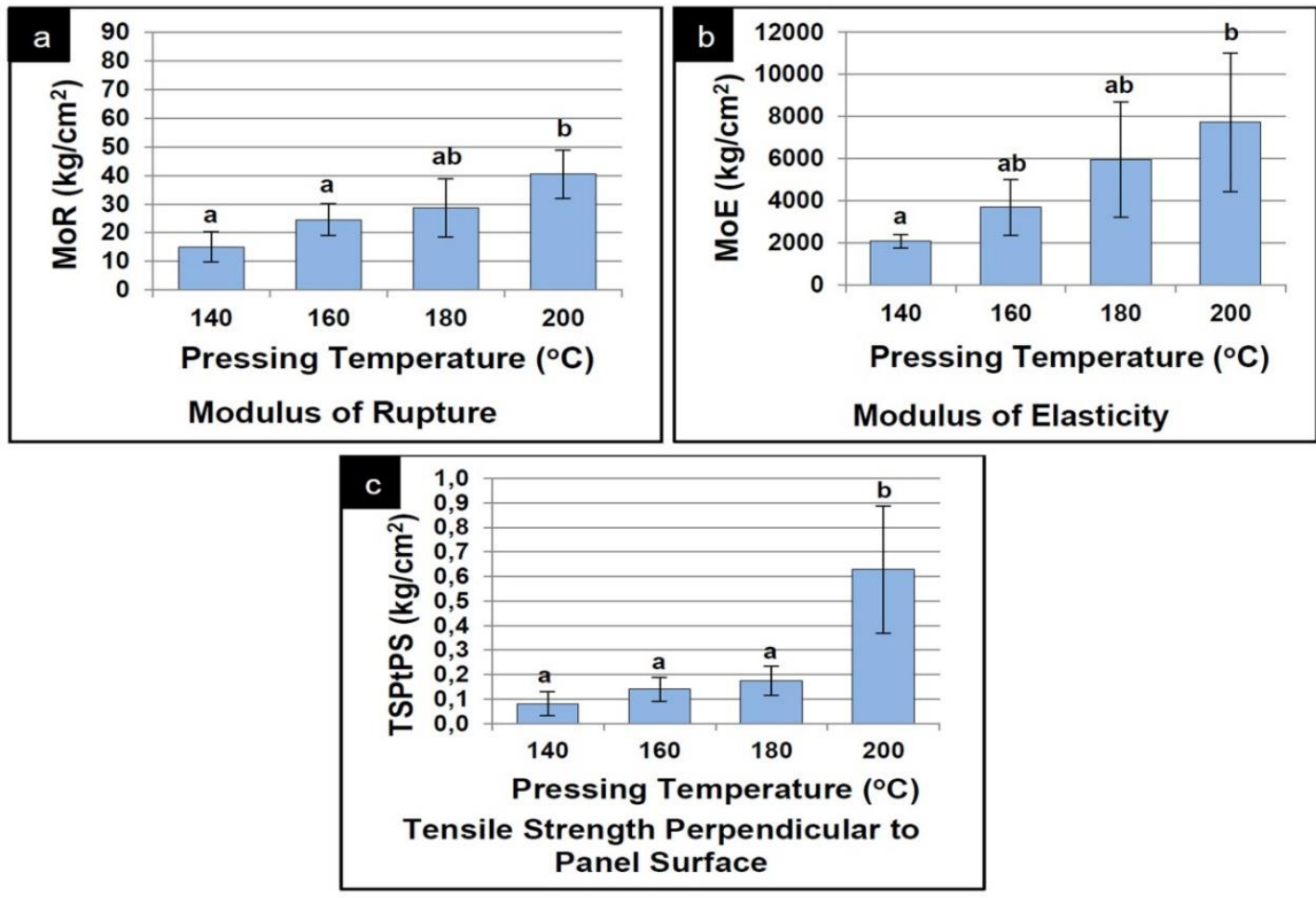

Fig. 8. The mechanical properties of BBP: (a) modulus of rupture; (b) modulus of elasticity; and (c) tensile strength perpendicular to the panel surface (means \pm the error bar shows the standard deviation and means with different letters are significantly different at $\alpha=0.05$ (Tukey's test)

Meanwhile, the MoE values showed a significant difference only between the 200 and $140{ }^{\circ} \mathrm{C}$ treatments, whereas, the values between the 160,180 , and $200{ }^{\circ} \mathrm{C}$ treatments did not show significant differences. For the TSPtPS values, there was a significant difference between the $200{ }^{\circ} \mathrm{C}$ pressing treatment and the 140,160 , and $180{ }^{\circ} \mathrm{C}$ treatments. The results of the Tukey's test revealed that increasing the pressing treatment temperature to 200 from $180{ }^{\circ} \mathrm{C}$ when making a low-density BBP was not sufficient to significantly increase the MoR. This is probably because, at a pressing temperature of $200{ }^{\circ} \mathrm{C}$ for 20 min, only a portion of the bark extractives are polymerized (Chow 1972). Furthermore, according to Chow (1972), most of the bark extractives that polymerized during the manufacturing process of wood bark board occurred at $200{ }^{\circ} \mathrm{C}$ for $80 \mathrm{~min}$, which resulted in the bending strength and IB values being similar to bark board with a $4.5 \% \mathrm{PF}$ adhesive. However, the use of this longer pressing time is impractical. It seems to indicate that the 
effect of plasticization still plays a prominent role in the formation of BBP at a pressing temperature of $200{ }^{\circ} \mathrm{C}$, i.e., it is possible the cure reaction is not yet working effectively. As pointed out by Araújo Junior et al. (2018), the cure reaction starts at a temperature of $210{ }^{\circ} \mathrm{C}$, and an effective cure occurs at a temperature of $220^{\circ} \mathrm{C}$. These principles also apply to the results of the Tukey's test for the MoE. For the TSPtPS values, a $200{ }^{\circ} \mathrm{C}$ treatment temperature resulted in a significant increase of the TSPtPS value from the $180{ }^{\circ} \mathrm{C}$ treatment TSPtPS value, which indicated that at $200{ }^{\circ} \mathrm{C}$, the polymerization of the phenolic materials had indeed occurred, even though only a small portion of the materials had polymerized. Figure $9 \mathrm{~b}$ shows that the failure line in the middle of the sample after TSPtPS testing could be associated with the stronger adhesion among the particles in the board pressed at a temperature of $200{ }^{\circ} \mathrm{C}$ compared to those pressed at $180{ }^{\circ} \mathrm{C}$. However, the results show that the TSPtPS value of BBP compressed at a temperature of $200{ }^{\circ} \mathrm{C}$ was still exceptionally low

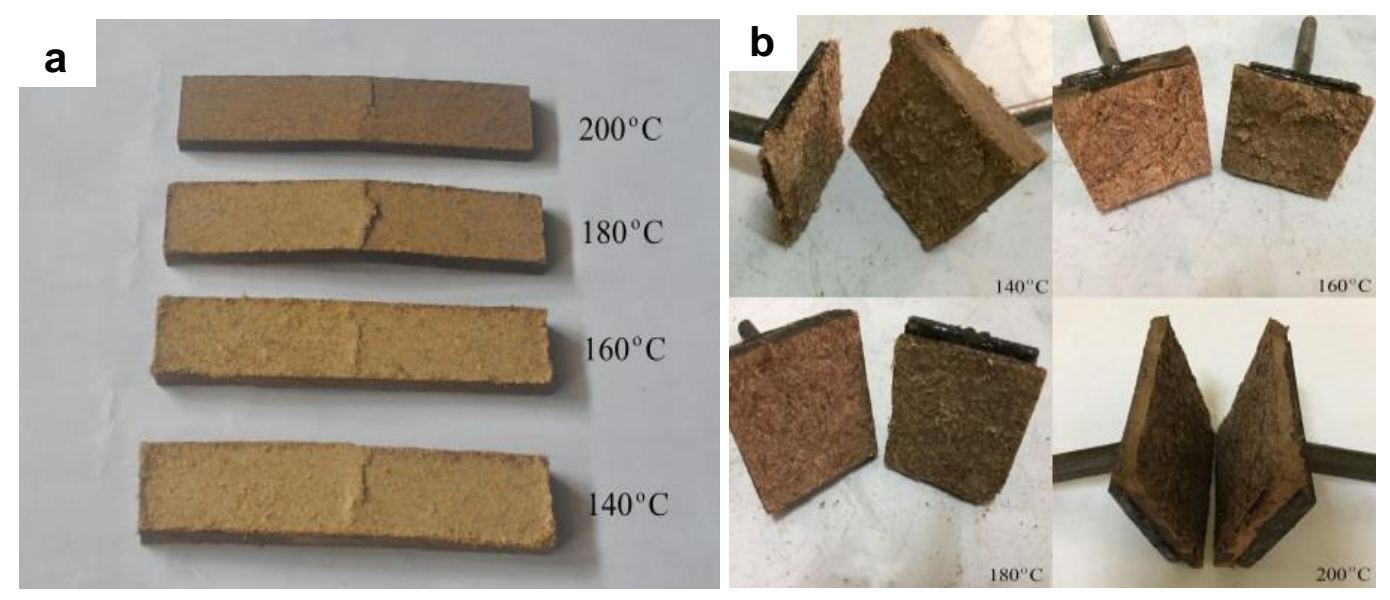

Fig. 9. Test samples after testing (a) the MoR and MoE; and (b) the TSPtPS of BBP pressed at a temperature of $140^{\circ} \mathrm{C}, 160^{\circ} \mathrm{C}, 180^{\circ} \mathrm{C}$, and $200^{\circ} \mathrm{C}$

Previous studies on manufacturing relatively high-density particleboards and fiberboards without adhesive via the hot-pressing method found that the mechanical properties of the board can be improved when the pressing temperature is increased to an optimum temperature of approximately $230{ }^{\circ} \mathrm{C}$ to $300^{\circ} \mathrm{C}$ (Chow 1975; Gao et al. 2011; Gupta et al. 2011; Nonaka et al. 2013). However, it should be noted that these boards used different starting materials. As mentioned by Nonaka et al. (2013), the optimum conditions were achieved in the manufacture of bagasse binderless particleboard at a temperature of approximately $260{ }^{\circ} \mathrm{C}$ with a short pressing time of $10 \mathrm{~min}$. These conditions result in an MoE equivalent to PMDI particleboard and a TS lower than PMDI particleboard. When manufacturing binderless fiberboard from refined bark, the best mechanical properties that also met the standard requirements were attained with a pressing temperature of $260^{\circ} \mathrm{C}$ for 6 min (Gao et al. 2011). In another study, Araújo Junior et al. (2018) showed that the optimum pressing temperature was slightly higher than $200{ }^{\circ} \mathrm{C}$ (more precisely at $220{ }^{\circ} \mathrm{C}$ for $4 \mathrm{~min}$ ), which resulted in high-density binderless fiberboard with good mechanical and physical properties being made from unripe coconut husks. Concerning the manufacturing of low-density BBP via the hot-pressing method, it is likely that temperatures higher than $200{ }^{\circ} \mathrm{C}$ are necessary. However, as mentioned previously at the beginning of this study, when the pressing temperature is raised above $200{ }^{\circ} \mathrm{C}$ for $20 \mathrm{~min}$, the boards become 
partially scorched. Nevertheless, if the pressing temperature is raised slightly higher than $200{ }^{\circ} \mathrm{C}$ for a shorter duration, this may result in a stronger bond between the bark particles, which in turn will improve the MoR, MoE, and TSPtPS of the board. Since there will be more phenolic polymerization, which becomes a dominant factor, this matter could be considering in future studies. Moreover, several methods have been proposed by other studies to improve the mechanical properties of binderless bark-based boards, e.g., chemical pre-treatment of the bark particles with a $1 \% \mathrm{NaOH}$ solution, pre-heating, and refining (Geng et al. 2006), as well as the addition of wood fibers (Gao et al. 2011).

Table 3. Comparison of the Mechanical and Physical Properties of the BBPs With Other Bark Boards Made via the Hot-Pressing Process With or Without the Addition of Adhesives

\begin{tabular}{|c|c|c|c|c|c|c|c|}
\hline Reference & \multicolumn{2}{|c|}{ This Work } & $\begin{array}{l}\text { (Sato } \\
2008)\end{array}$ & $\begin{array}{l}\text { (Purwanto } \\
\text { 2015) }\end{array}$ & \multicolumn{3}{|c|}{ (Gupta et al. 2011) } \\
\hline Material & \multicolumn{2}{|c|}{ GBW $^{1}$} & $\begin{array}{c}\text { Melaleuca } \\
\text { bark }^{2}\end{array}$ & $\begin{array}{c}\text { Galam tree bark } \\
\text { (Melaleuca } \\
\text { leucadendra L.) }\end{array}$ & \multicolumn{3}{|c|}{$\begin{array}{l}\text { Beetle-infested lodgepole pine } \\
\quad \text { (Pinus contorta) bark }{ }^{4}\end{array}$} \\
\hline $\mathrm{T}\left({ }^{\circ} \mathrm{C}\right)$ & 180 & 200 & 180 & 110 to 120 & 170 & 200 & 230 \\
\hline $\begin{array}{c}\text { Pressure } \\
\left(\mathrm{kg} / \mathrm{cm}^{2}\right) \\
\text { Time } \\
(\mathrm{min})\end{array}$ & $30 ; 20$ & $30 ; 20$ & $40.79 ; 15$ & $15 ; 15$ & $\begin{array}{c}28.1 ; 1 \\
\text { followed } \\
\text { by } \\
12.3 ; 19\end{array}$ & $\begin{array}{c}28.1 ; 1 \\
\text { followed } \\
\text { by } \\
12.3 ; 19\end{array}$ & $\begin{array}{c}28.1 ; 1 \\
\text { followed } \\
\text { by } \\
12.3 ; 19\end{array}$ \\
\hline $\begin{array}{c}\text { MoR } \\
\left(\mathrm{kg} / \mathrm{cm}^{2}\right)\end{array}$ & 28.7 & 40.5 & $\begin{array}{c}\text { Approx. } \\
28.55 \text { to } \\
45.89\end{array}$ & 104.2 & 20.5 & 32.8 & 73.2 \\
\hline $\begin{array}{c}\mathrm{MoE} \\
\left(\mathrm{kg} / \mathrm{cm}^{2}\right)\end{array}$ & 5947 & 7730 & $\begin{array}{c}\text { Approx } \\
1019.72 \\
\text { to } \\
1325.63\end{array}$ & 8191 & 4283 & 7383 & 17200 \\
\hline $\begin{array}{c}\text { TSPtPS/ } \\
\text { IB } \\
\left(\mathrm{kg} / \mathrm{cm}^{2}\right)\end{array}$ & 0.17 & 0.63 & $0.31-0.41$ & 0.65 & 1.02 & 1.53 & 9.89 \\
\hline $\begin{array}{l}\text { Density } \\
\left(\mathrm{g} / \mathrm{cm}^{3}\right)\end{array}$ & 0.52 & 0.55 & $0.80^{(+)}$ & 0.77 & 0.80 & 0.86 & 0.92 \\
\hline $\begin{array}{c}\text { TS24h } \\
(\%)\end{array}$ & 12.93 & 4.94 & $\begin{array}{l}\text { Approx. } \\
0.70 \text { to } 2\end{array}$ & 2 & 64.93 & 41.77 & 10.46 \\
\hline $\begin{array}{l}\text { WA24h } \\
(\%)\end{array}$ & 21.4 & 16.3 & 8 to 10 & - & 72.82 & 57.27 & 15.36 \\
\hline $\begin{array}{cc}1 & \begin{array}{l}\text { Low-de } \\
\text { High-de }\end{array} \\
& \begin{array}{l}\text { (mesh } \\
3 \\
\text { Medium } \\
\text { bark pi }\end{array} \\
4 & \begin{array}{l}\text { Bark bo } \\
\text { through }\end{array} \\
(+) & \text { Target d }\end{array}$ & $\begin{array}{l}\text { sity BBP } \\
\text { sity bark } \\
\text { ze } 50 \mathrm{mr} \\
\text { density } \\
\text { es } 6 \mathrm{~cm} \\
\text { rd witho } \\
4 \text { mesh s } \\
\text { nsity }\end{array}$ & $\begin{array}{l}\text { single-le } \\
\text { inderle } \\
\times 100 \mathrm{n} \\
\text { iticlebo } \\
\text { length } \\
\text { synthe } \\
\mathrm{e}\end{array}$ & $\begin{array}{l}\text { er; thicknes } \\
\text { board; sing } \\
\text { n) } \\
\text { rd with } 15 \% \\
\text { adhesive; }\end{array}$ & $\begin{array}{l}\text { ff } 10 \mathrm{~mm} \text {; particle } \\
\text {-layer; target thic } \\
\text { = resin; single-las } \\
\text { gle-layer; thickne }\end{array}$ & $\begin{array}{l}\text { passed t } \\
\text { ness of } 1 \\
\text {; thickne } \\
\text { s of } 6.25\end{array}$ & $\begin{array}{l}\text { rough } 10 \\
\mathrm{~mm} \text {; bark } \\
\text { ss of } 10 \mathrm{mr} \\
\mathrm{nm} \text {; particl }\end{array}$ & $\begin{array}{l}\text { lesh size } \\
\text { lakes } \\
\text { s Galam } \\
\text { s passed }\end{array}$ \\
\hline
\end{tabular}

Based on SNI standard 03-2105-2006 (2006), the MoR, MoE, and TSPtPS values of the BBP manufactured in this study did not meet the minimum requirements for Type8 (a MoR of $82 \mathrm{~kg} / \mathrm{cm}^{2}$, a MoE of $20400 \mathrm{~kg} / \mathrm{cm}^{2}$, and a TSPtPS of $\left.1.5 \mathrm{~kg} / \mathrm{cm}^{2}\right)$. Nonetheless, it can be said that the low mechanical properties of the board panel made without adhesives are due to the low strength of the bark, i.e., the fibers of the bark are shorter and weaker 
than wood fibers, and the proportion of its fibers is lower than wood (Geng et al. 2006; Gao et al. 2011; Hosseinihashemi et al. 2017).

Table 3 compares the properties of the BBPs manufactured in this study with other bark boards made via the hot-pressing process, with or without the addition of adhesives. The MoR values of BBPs that have been pressed at a temperature of 180 and $200{ }^{\circ} \mathrm{C}$ were still within range of the MoR values of a high-density binderless board made from the bark of Melaleuca pressed at a temperature of $180{ }^{\circ} \mathrm{C}$ (Sato 2008). However, BBP pressed at a temperature of $200{ }^{\circ} \mathrm{C}$ had better mechanical properties (MoE and TSPtPS) than a highdensity binderless bark board. The MoR and MoE of BBP pressed at a temperature of 200 ${ }^{\circ} \mathrm{C}$ had lower MoR and MoE values $(61.13 \%$ and $5.63 \%$, respectively) than mediumdensity particleboard made from Galam bark using a $15 \%$ urea formaldehyde (UF) adhesive, even though the TSPtPS values of the two boards were similar. After comparing the TSPtPS values listed in Table 3, it was found that the adhesive-free method for making particleboard from Gelam bark was more favorable than using UF adhesive; however, further studies are necessary to confirm this. In addition, a comparison of the MoR and $\mathrm{MoE}$ values of the $\mathrm{BBP}$ pressed at a temperature of 180 and $200{ }^{\circ} \mathrm{C}$ with bark board manufactured without synthetic adhesive pressed at a temperature of 170 and $200{ }^{\circ} \mathrm{C}$ revealed similar MoR and MoE values (Gupta et al. 2011). However, the TSPtPS values of the BBP samples were much lower. Raising the pressing temperature to $230{ }^{\circ} \mathrm{C}$, as demonstrated in the study by Gupta et al. (2011), produced a board with higher mechanical properties than the BBP pressed at a temperature of $200^{\circ} \mathrm{C}$.

\section{Physical Properties}

Figure 10 shows the average values of the density, MC, TS24h, and WA24h of the BBP pressed at different pressing temperatures. Based on the analysis of variance, the pressing temperature had a significant influence on the physical properties of the BBPs (ANOVA $p$-value was less than 0.01).

The board density increased as the temperature was increased. On average, the density of the BBPs, based on the variations of the pressing temperatures, ranged from 0.44 to $0.55 \mathrm{~g} / \mathrm{cm}^{3}$, which met the requirement of SNI standard 03-2105-2006 (2006), i.e., 0.40 $\mathrm{g} / \mathrm{cm}^{3}$ to $0.90 \mathrm{~g} / \mathrm{cm}^{3}$. These results categorize the manufactured BBPs as low-density particleboards (a density of less than or equal to $0.59 \mathrm{~g} / \mathrm{cm}^{3}$ ). The boards can be made with low-density because GBW has low-density. According to Roussan (1923), Melaleuca bark has a low specific gravity (0.18 to 0.20$)$. Xu et al. (2004) asserted that low-density particleboards could only be made from low-density raw materials. There was a significant difference between the density value of the BBP pressed at a temperature of $140{ }^{\circ} \mathrm{C}$ with the BBPs pressed at the other tested temperatures; the BBP pressed at $140^{\circ} \mathrm{C}$ had the lowest density value $\left(0.44 \mathrm{~g} / \mathrm{cm}^{3}\right)$. This is probably caused by the spring-back effect that occurs after the pressing process and the swelling that may occur during the conditioning (Iswanto et al. 2014, 2019), therefore decreasing its density. This aspect is also closely related to the TSPtPS value of the BBP (at a pressing temperature of $140{ }^{\circ} \mathrm{C}$ ), which was poor and therefore not high enough to hold the particles in a compressed form when the pressure was released (Pintiaux et al. 2015). Furthermore, the density of the $160{ }^{\circ} \mathrm{C}$ treatment significantly differed from the density of the $200{ }^{\circ} \mathrm{C}$ treatment. However, there was no significant difference between density of the $160{ }^{\circ} \mathrm{C}$ treatment and the $180{ }^{\circ} \mathrm{C}$ treatment, nor was there a significant difference between the $180{ }^{\circ} \mathrm{C}$ treatment and the $200{ }^{\circ} \mathrm{C}$ treatment. 

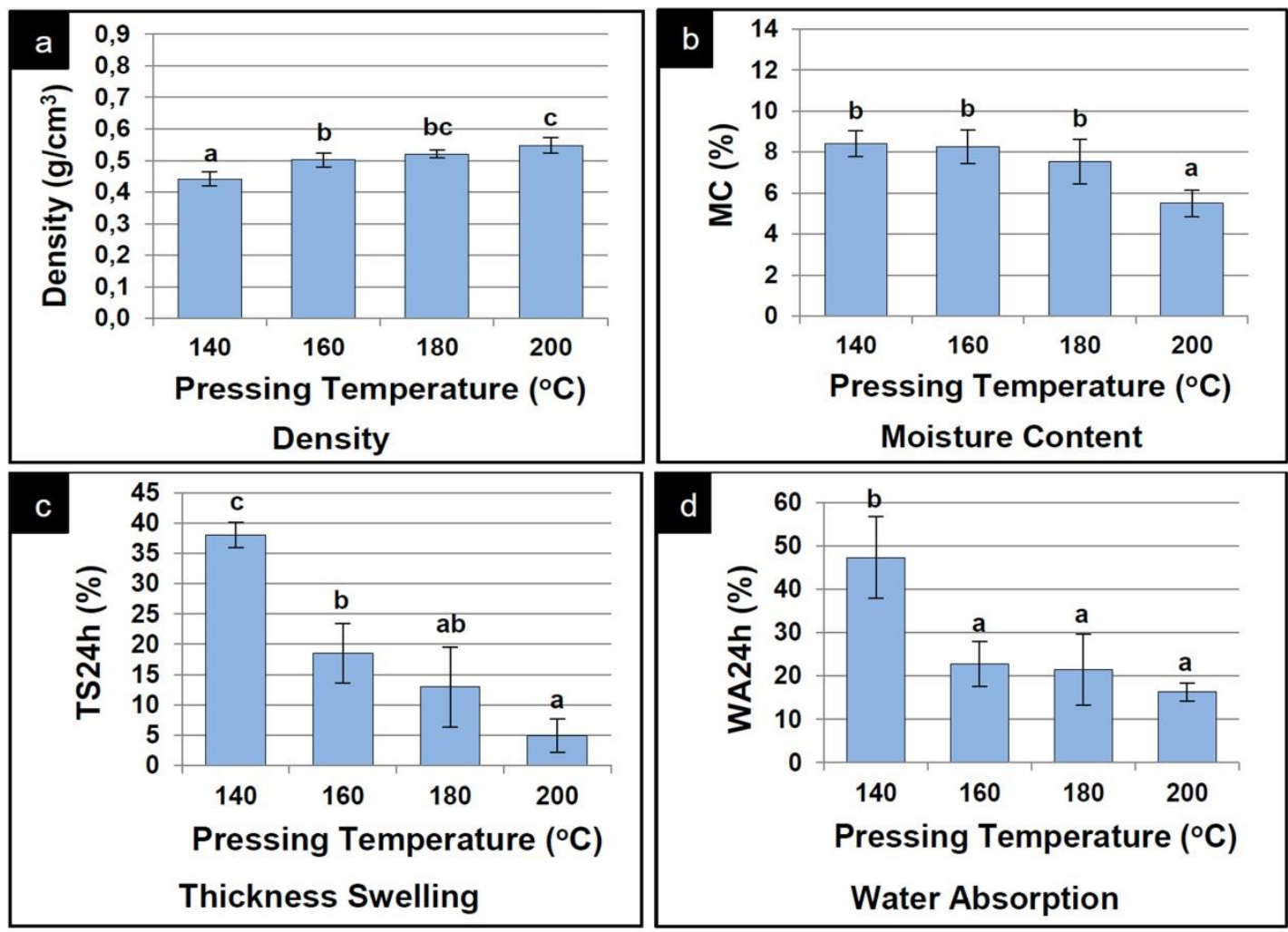

Fig. 10. The physical properties of the BBP: (a) density; (b) moisture content; (c) thickness swelling after $24 \mathrm{~h}$ of soaking; (d) water absorption after $24 \mathrm{~h}$ of soaking (means \pm the error bar shows the standard deviation and means with different letters are significantly different at $\alpha=$ 0.05 (Tukey's test)

The average MCs of the manufactured boards ranged from $5.50 \%$ to $8.39 \%$. The lowest MC was found in the board that was pressed at a temperature of $200{ }^{\circ} \mathrm{C}(5.50 \%)$, and it met the requirements of SNI standard 03-2105-2006 (2006), i.e., less than or equal to $14 \%$. The $\mathrm{MC}$ of the board manufactured at pressing temperature of $200{ }^{\circ} \mathrm{C}$ was significantly different from the MCs of the boards at pressing temperatures of 140, 160, and $180{ }^{\circ} \mathrm{C}$. However, there was no significant difference between those three treatments.

The TS24h of the BBPs decreased from $38.06 \%$ to $4.94 \%$ as the pressing temperature increased from 140 to $200{ }^{\circ} \mathrm{C}$. The treatment with a $200{ }^{\circ} \mathrm{C}$ pressing temperature significantly differed from the 140 and $160{ }^{\circ} \mathrm{C}$ treatments, in terms of the TS24h, but did not significantly different from the $180{ }^{\circ} \mathrm{C}$ treatment. The BBP made at a $200{ }^{\circ} \mathrm{C}$ pressing temperature had good dimensional stability since its TS24 h value met the requirements of the SNI standard 03-2105-2006 (2006) for the maximum thickness swelling (12\%). Meanwhile, when the pressing temperature was increased from 140 to 200 ${ }^{\circ} \mathrm{C}$, the WA24h value decreased from $47.35 \%$ to $16.3 \%$. The WA24h value of the board pressed at a temperature of $200{ }^{\circ} \mathrm{C}$ was not significantly different from the board pressed at a temperature of 160 and $180{ }^{\circ} \mathrm{C}$. However, the boards made at a pressing temperature of 160,180 , and $200{ }^{\circ} \mathrm{C}$ all significantly differed from the board pressed at a temperature of $140{ }^{\circ} \mathrm{C}$.

A higher pressing temperature will lower the TS24h and WA24h values, since a higher pressing temperature will create a stronger bond between the board particles. This 
phenomenon will make the board denser, i.e., reduce or completely remove any void spaces between the particles, as shown by the SEM micrographs of the surfaces and the crosssections (Figs. 5d and 6d); therefore, the water penetration of the board structure is reduced. Furthermore, there are also the lignins that flow onto the surfaces of the GBW particles (Fig. 5d). Since lignins are hydrophobic by nature, with non-polar hydrocarbon chains and aromatic rings that prevent water from entering (which can cause swelling in the cell wall), they cause an increased resistance to water penetration (Mancera et al. 2011; Nasir et al. 2019). Another aspect to consider is the reduction in the amount of hydroxyl groups that are easily accessible by water, due to hemicellulose degradation (Kurokochi and Sato 2020; Nitu et al. 2020; Song et al. 2020), which was also confirmed by the FTIR spectra of BBP in the present study. This view is also in line with the study by Gao et al. (2011), which asserted that a low TS value is associated with the polymerization, cross-linking, and/or other transformations of hydrophilic components of bark into a hydrophobic product during hot pressing under high temperature for a sufficient period.

Table 3 shows that the board made from GBW pressed at a temperature of $200{ }^{\circ} \mathrm{C}$ had a lower TS24h value than the board make by Gupta et al. (2011). However, the TS24h was still higher when compared to the medium-density particleboards made in Purwanto (2015) and the high-density bark binderless boards made by Sato (2008). The WA24h value of the BBP pressed at a temperature of $200{ }^{\circ} \mathrm{C}$ was similar to the WA24h value of the bark boards made by Gupta et al. (2011), i.e., the board pressed at a temperature of 230 ${ }^{\circ} \mathrm{C}$. The results of the TS24h and WA24h tests showed that boards made from Melaleuca bark had high dimensional stability and water resistance.

Figure 11 shows the TS24h and WA24h test samples (BBP pressed at 140, 160, 180 , and $200^{\circ} \mathrm{C}$ ) after testing. It can be seen that they did not disintegrate.

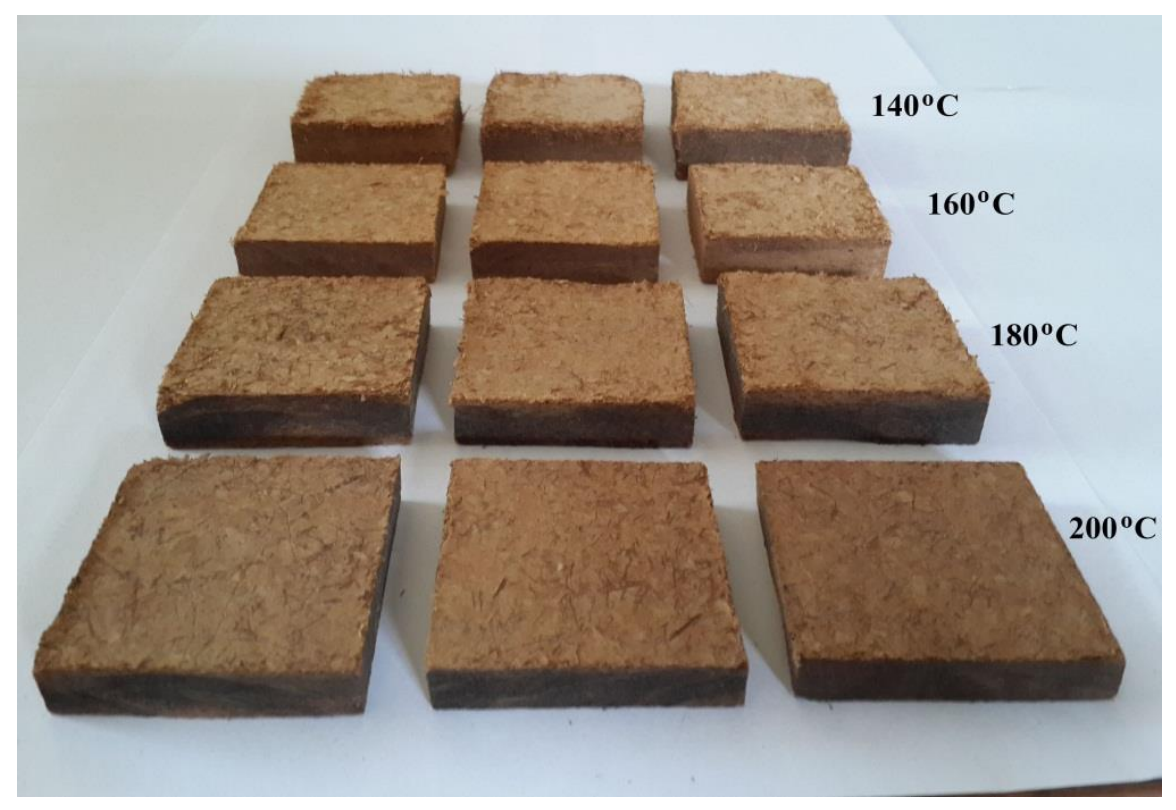

Fig. 11. The BBP test samples pressed at $140,160,180$, and $200^{\circ} \mathrm{C}$ after the TS24h and WA24h tests

\section{Thermal Conductivity}

A thermal conductivity test was performed, considering that BBP was a low-density board category. Since it was mentioned by Panyakaew and Fotios (2011) that a low-density 
board tends to have a lower thermal conductivity than a high-density board, it is appropriate for usage as thermal insulation. Only the boards pressed at a temperature of $200{ }^{\circ} \mathrm{C}$ (density value $0.55 \mathrm{~g} / \mathrm{cm}^{3}$ ) were tested, since these boards had the best physical and mechanical properties among the four types of boards pressed at different temperatures. Kain et al. (2014) found that a certain level of compaction in the insulation board, i.e., a density of greater than or equal to $400 \mathrm{~kg} / \mathrm{m}^{3}$, was required to meet the relevant mechanical property standards.

A comparison of thermal conductivity value of the BBP pressed at a temperature of $200{ }^{\circ} \mathrm{C}$ with conventional and natural insulation materials is shown in Table 4. The comparison showed that the thermal conductivity value of the BBP pressed at a temperature of $200{ }^{\circ} \mathrm{C}$ was not as low as the lightweight insulation materials (rock wool and expanded polystyrene). However, it was still higher than natural insulation materials, e.g., kenaf, flax shives, sunflower bark, eucalyptus bark, poplar bark particles, larch bark particles, and coconut husk, but it is was comparable with others materials from Quercus cerris bark (particleboards with a density of $725 \mathrm{~kg} / \mathrm{m}^{3}$ ), wood particles, green coconut, and sugarcane bagasse fiber (multilayer particleboards with a density of $500 \mathrm{~kg} / \mathrm{m}^{3}$ ); it was also slightly lower than green coconut and sugarcane bagasse fiber (multilayers particleboards with a density of $700 \mathrm{~kg} / \mathrm{m}^{3}$ ). These results revealed that BBP pressed at a temperature of $200{ }^{\circ} \mathrm{C}$ had a high thermal conductivity value. This may be related to the fact that there were almost no voids of air pockets in the board, which can be confirmed by the results of the SEM micrographs showing the cross-section of the BBP (Fig. 6d), as it is known that air is a poor conductor of heat (Zhou et al. 2010; Liao et al. 2016; Fiorelli et al. 2019). However, the insulation boards from natural materials with low thermal conductivity values usually have densities less than or equal to $0.40 \mathrm{~g} / \mathrm{cm}^{3}$ since they have a large number of voids, which are filled with air. According to Asdrubali et al. (2015), the best material will have a thermal conductivity value of less than $0.05 \mathrm{~W} / \mathrm{m} \cdot \mathrm{K}$. However, Zhou et al. (2010) and Fiorelli et al. (2019) claimed that in general, any material with thermal conductivity of less than $0.25 \mathrm{~W} / \mathrm{m} \cdot \mathrm{K}$ could be considering as thermal insulation material.

Relating to the usage of BBP pressed at $200{ }^{\circ} \mathrm{C}$, its values of MoR $\left(40.5 \mathrm{~kg} / \mathrm{cm}^{2}\right)$, $\operatorname{MoE}\left(7730 \mathrm{~kg} / \mathrm{cm}^{2}\right)$, and TSPtPS $\left(0.63 \mathrm{~kg} / \mathrm{cm}^{2}\right)$ were lower than the minimum required values SNI standard 03-2105-2006 for type 8; and hence they can be considered for thermal insulation materials. This consideration is taken by looking at the mechanical properties of BBP pressed at $200{ }^{\circ} \mathrm{C}$ compared with thermal insulators from natural/waste materials from other experimental studies. These mechanical properties (MoR and MoE values) of BBP were higher than Quercus cerris bark particleboards (density 550 to $725 \mathrm{~kg} / \mathrm{m}^{3}$, thermal conductivity 0.11 to $0.14 \mathrm{~W} / \mathrm{m} \cdot \mathrm{K}$, MoR 0.71 to $1.52 \mathrm{MPa}$, MoE 58.5 to $143.6 \mathrm{MPa}$, IB 0.18 to $0.28 \mathrm{MPa}$ ) (Lakreb et al. 2018). The TSPtPS/IB value of BBP pressed at $200{ }^{\circ} \mathrm{C}$ was lower than those particleboards. Further, they recommend Quercus cerris bark particleboards for exterior non-load bearing applications (shed roof insulation). Then, the MoR, MoE, and TSPtPS values of BBP slightly higher compared with thermal insulating particleboard reinforced with coconut leaf sheaths (density $410 \mathrm{~kg} / \mathrm{m}^{3}$, thermal conductivity $0.135 \mathrm{~W} / \mathrm{m} \cdot \mathrm{K}$, MoR $3.82 \mathrm{MPa}, \mathrm{MoE} 455 \pm 94 \mathrm{MPa}$, IB $0.05 \mathrm{MPa}$ ), which stated to have the potential to be applied as a material building insulation (partition walls, ceiling coatings, and internal doors) (Vidil et al. 2016). Indeed in the building insulator sector, mechanical properties are not primary characterizations (Gupta and Maji 2020). 
Table 4. Comparison of the Thermal Conductivity Value of the BBP Pressed at a Temperature of $200{ }^{\circ} \mathrm{C}$ with Conventional and Natural Insulation Materials

\begin{tabular}{|c|c|c|c|c|c|c|}
\hline Material & Board Type & Density & $\begin{array}{l}\text { Thickness } \\
(\mathrm{mm})\end{array}$ & $\begin{array}{l}\text { Resin } \\
\text { Type }\end{array}$ & $\begin{array}{c}\lambda \\
(\mathrm{W} / \mathrm{m} \cdot \mathrm{K})\end{array}$ & References \\
\hline GBW & $\begin{array}{l}\text { Binderless } \\
\text { bark } \\
\text { particleboard }\end{array}$ & $\begin{array}{c}0.55 \\
\mathrm{~g} / \mathrm{cm}^{3}\end{array}$ & 10 & - & 0.14 & This work \\
\hline Rock wool & - & $\begin{array}{c}40 \\
\mathrm{~kg} / \mathrm{m}^{3} \text { to } \\
200 \\
\mathrm{~kg} / \mathrm{m}^{3} \\
\end{array}$ & - & - & $\begin{array}{c}0.033 \text { to } \\
0.040\end{array}$ & $\begin{array}{l}\text { (Asdrubali } \\
\text { et al. 2015) }\end{array}$ \\
\hline $\begin{array}{c}\text { Expanded } \\
\text { polystyrene } \\
\text { (EPS) }\end{array}$ & - & $\begin{array}{c}15 \\
\mathrm{~kg} / \mathrm{m}^{3} \text { to } \\
35 \\
\mathrm{~kg} / \mathrm{m}^{3}\end{array}$ & - & - & $\begin{array}{c}0.031 \text { to } \\
0.038\end{array}$ & $\begin{array}{l}\text { (Asdrubali } \\
\text { et al. 2015) }\end{array}$ \\
\hline Kenaf & $\begin{array}{l}\text { Binderless } \\
\text { particleboard }\end{array}$ & $\begin{array}{c}0.15 \\
\mathrm{~g} / \mathrm{cm}^{3 *} \\
\text { and } \\
0.20 \\
\mathrm{~g} / \mathrm{cm}^{3 *}\end{array}$ & 12 & - & $\begin{array}{l}0.051 \\
\text { and } \\
0.058\end{array}$ & $\begin{array}{c}\text { (Xu et al. } \\
2004)\end{array}$ \\
\hline Flax shives & $\begin{array}{c}\text { Binderless } \\
\text { particleboard }\end{array}$ & $\begin{array}{c}500 \\
\mathrm{~kg} / \mathrm{m}^{3 *}\end{array}$ & 15 & - & 0.077 & $\begin{array}{l}\text { (Mahieu et } \\
\text { al. 2019) }\end{array}$ \\
\hline $\begin{array}{c}\text { Sunflower } \\
\text { bark }\end{array}$ & $\begin{array}{c}\text { Binderless } \\
\text { particleboard }\end{array}$ & $\begin{array}{c}500 \\
\mathrm{~kg} / \mathrm{m}^{3 *}\end{array}$ & 15 & - & 0.077 & $\begin{array}{l}\text { (Mahieu et } \\
\text { al. 2019) }\end{array}$ \\
\hline $\begin{array}{l}\text { Eucalyptus } \\
\text { bark fibers }\end{array}$ & $\begin{array}{l}\text { Insulation } \\
\text { panel }\end{array}$ & $\begin{array}{c}25 \\
\mathrm{~kg} / \mathrm{m}^{3} \text { to } \\
100 \\
\mathrm{~kg} / \mathrm{m}^{3}\end{array}$ & 50 & $\begin{array}{l}\text { Synthetic } \\
\text { fibers }\end{array}$ & $\begin{array}{c}0.045 \text { to } \\
0.049\end{array}$ & $\begin{array}{l}\text { (Casas- } \\
\text { Ledón et al. } \\
2020)\end{array}$ \\
\hline $\begin{array}{l}\text { Poplar bark } \\
\text { particles }\end{array}$ & Particleboard & $\begin{array}{l}250 \\
\mathrm{~kg} / \mathrm{m}^{3 *} \\
\text { to } 350 \\
\mathrm{~kg} / \mathrm{m}^{3 *}\end{array}$ & 20 & $8 \%$ UF & $\begin{array}{c}0.059 \text { to } \\
0.079\end{array}$ & $\begin{array}{l}\text { (Pásztory et } \\
\text { al. 2019) }\end{array}$ \\
\hline $\begin{array}{l}\text { Larch bark } \\
\text { particles }\end{array}$ & $\begin{array}{l}\text { Insulation } \\
\text { board }\end{array}$ & $\begin{array}{c}500 \\
\mathrm{~kg} / \mathrm{m}^{3 *}\end{array}$ & 20 & $\begin{array}{c}\text { Tannin } \\
\text { hexamine }\end{array}$ & 0.093 & $\begin{array}{l}\text { (Kain et al. } \\
\text { 2014) }\end{array}$ \\
\hline $\begin{array}{l}\text { Quercus } \\
\text { cerris bark }\end{array}$ & Particleboard & $\begin{array}{l}550 \\
\mathrm{~kg} / \mathrm{m}^{3 *} \\
\text { to } 725 \\
\mathrm{~kg} / \mathrm{m}^{3 *}\end{array}$ & 10 & $10 \% \mathrm{PF}$ & $\begin{array}{c}0.11 \text { to } \\
0.14\end{array}$ & $\begin{array}{l}\text { (Lakreb et } \\
\text { al. 2018) }\end{array}$ \\
\hline $\begin{array}{c}\text { Wood } \\
\text { particles }\end{array}$ & Particleboard & - & & & $\begin{array}{c}0.10 \text { to } \\
0.14\end{array}$ & $\begin{array}{l}\text { (Lakreb et } \\
\text { al. 2018) }\end{array}$ \\
\hline $\begin{array}{l}\text { Coconut } \\
\text { husk }\end{array}$ & $\begin{array}{c}\text { Binderless } \\
\text { insulation } \\
\text { board }\end{array}$ & $\begin{array}{c}0.48 \\
\mathrm{~g} / \mathrm{cm}^{3}\end{array}$ & 25 & & 0.115 & $\begin{array}{c}\text { (Panyakaew } \\
\text { and Fotios } \\
\text { 2011) }\end{array}$ \\
\hline $\begin{array}{c}\text { Green } \\
\text { coconut } \\
\text { and } \\
\text { sugarcane } \\
\text { bagasse } \\
\text { fiber }\end{array}$ & $\begin{array}{c}\text { Multilayer } \\
\text { particleboard } \\
\text { s }\end{array}$ & $\begin{array}{c}500 \\
\mathrm{~kg} / \mathrm{m}^{3} \\
\text { and } 700 \\
\mathrm{~kg} / \mathrm{m}^{3}\end{array}$ & 15 & $\begin{array}{l}\text { Castor oil } \\
\text { polyurethane } \\
\text { resin }\end{array}$ & $\begin{array}{l}0.14 \\
\text { and } \\
0.17\end{array}$ & $\begin{array}{l}\text { (Fiorelli et } \\
\text { al. 2019) }\end{array}$ \\
\hline
\end{tabular}

However, if thermal insulation materials contributed to building structures, such as those applied to wall and roof surfaces, it requires at least adequate mechanical properties. Because according to Liu et al. (2017), several types of insulation are always directly installed on the surface of a wall or roof and facing the collision of hard objects. Also, 
Wood-based panels, as thermal insulation panels, should withstand a minimum performance during handling, installation, and maintenance (Pásztory et al., 2019). The competitive advantage of BBP pressed at $200{ }^{\circ} \mathrm{C}$ is its high-water resistance compared to the aforementioned thermal insulators from natural/waste materials. Then BBP may be used for exterior purposes.

Based on the consideration of the thermal conductivity of BBP pressed at $200{ }^{\circ} \mathrm{C}$ combined with its mechanical and physical properties, so BBP pressed at $200{ }^{\circ} \mathrm{C}$ potentially uses for thermal insulation in buildings. Additionally, this thermal insulation material environmentally friendly since without formaldehyde adhesive.

\section{CONCLUSIONS}

1. The results showed that the pressing temperature affected the physical and mechanical properties of the manufactured boards. As the pressing temperature was increased from $140{ }^{\circ} \mathrm{C}$ to $200{ }^{\circ} \mathrm{C}$, the average values of the mechanical properties also increased, even though the increase was not significant for the MoR and MoE values at pressing temperatures of $180{ }^{\circ} \mathrm{C}$ and $200{ }^{\circ} \mathrm{C}$. However, the TSPtPS values significantly differed with different pressing temperatures. All the mechanical properties of the boards did not meet SNI standard 03-2105-2006 for Type-8 (2006). For the physical properties, the density increased as the pressing temperature increased, while the MC, TS24h, and WA24h decreased as the pressing temperature increased. The decreasing TS24h and WA24h values did not significantly differ for the 180 and $200{ }^{\circ} \mathrm{C}$ treatments. The BBPs pressed at a temperature of 140 to $200{ }^{\circ} \mathrm{C}$ had density and $\mathrm{MC}$ values that met the SNI standard 03-2105-2006 (2006). In addition, the TS24h values of the BBP pressed at a temperature of $200{ }^{\circ} \mathrm{C}$ was the only sample to meet SNI standard 03-2105-2006 (2006) requirements for the maximum thickness swelling (12\%).

2. The best physical and mechanical properties were obtained from the BBP pressed at a temperature of $200{ }^{\circ} \mathrm{C}$ with a MoR value of $40.5 \mathrm{~kg} / \mathrm{cm}^{2}$, a MoE value of $7730 \mathrm{~kg} / \mathrm{cm}^{2}$, a TSPtPS value of $0.63 \mathrm{~kg} / \mathrm{cm}^{2}$, a TS24h value of $4.94 \%$, and a WA24h value of $16.3 \%$.

3. The thermal conductivity value of the BBP pressed at a temperature of $200{ }^{\circ} \mathrm{C}$ with a density of $0.55 \mathrm{~g} / \mathrm{cm}^{3}$ was $0.14 \mathrm{~W} / \mathrm{m} \cdot \mathrm{K}$. Therefore, it can still be taken into account as thermal insulation material for use in buildings. Besides, its low mechanical properties and also better thickness swelling value adequate for that usage.

4. The BBP pressed at a temperature of $200{ }^{\circ} \mathrm{C}$ had a smooth surface and had high-water resistance properties; therefore, it could potentially be used as an overlay material/surface layer in composite panels, such as a decorative insulation panel.

\section{ACKNOWLEDGMENTS}

The authors would like to thank the Ministry of Research, Technology, and Higher Education of the Republic of Indonesia for providing them with a postgraduate scholarship. 


\section{REFERENCES CITED}

Ahmad, Z., Tajuddin, M., Maleque, A., and Halim, Z. (2019). "Effects of particle sizes on the properties of binderless boards made from rattan furniture waste," Journal of Engineering Science 15, 49-61. DOI: 10.21315/jes2019.15.5

Araújo Junior, C. P., Coaquira, C. A. C., Mattos, A. L. A., Filho, M. d. S. M. d. S., Feitosa, J. P. de A., Morais, J. P. S. de, and Rosa, M. d. F. (2018). "Binderless fiberboards made from unripe coconut husks," Waste and Biomass Valorization 9(11), 2245-2254. DOI: 10.1007/s12649-017-9979-9

Asdrubali, F., D’Alessandro, F., and Schiavoni, S. (2015). "A review of unconventional sustainable building insulation materials," Sustainable Materials and Technologies 4, 1-17. DOI: $10.1016 /$ j.susmat.2015.05.002

ASTM D1103-60 (1977). "Method of test for alpha-cellulose in wood," ASTM International, West Conshohocken, PA.

Boon, J. G., Hashim, R., Sulaiman, O., Hiziroglu, S., Sugimoto, T., and Sato, M. (2013). "Influence of processing parameters on some properties of oil palm trunk binderless particleboard," European Journal of Wood and Wood Products 71(5), 583-589. DOI: 10.1007/s00107-013-0712-5

Casas-Ledón, Y., Salgado, K. D., Cea, J., Arteaga-Pérez, L. E., and Fuentealba, C. (2020). "Life cycle assessment of innovative insulation panels based on eucalyptus bark fibers," Journal of Cleaner Production 249, 1-10. DOI: 10.1016/j.jclepro.2019.119356

Chen, H., and Yan, N. (2018). "Application of Western red cedar (Thuja plicata) tree bark as a functional filler in pMDI wood adhesives," Industrial Crops and Products 113, 1-9. DOI: 10.1016/j.indcrop.2018.01.005

Chiang, S.-H. T., and Wang, S. (1984). "The structure and formation of melaleuca bark," Wood and Fiber Science 16(3), 357-373.

Chow, S. (1972). "Thermal reactions and industrial uses of bark," Wood and Fiber Science 4(3), 130-138.

Chow, S. (1975). "Bark boards without synthetic resins," Forest Products Journal 25(11), 32-37.

Chow, S.-Z., and Pickles, K. J. (1971). "Thermal softening and degradation of wood and bark," Wood and Fiber Science 3(3), 166-178.

Dang, B., Chen, Y., Wang, H., Chen, B., Jin, C., and Sun, Q. (2018). "Preparation of high mechanical performance nano- $\mathrm{Fe}_{3} \mathrm{O}_{4} /$ wood fiber binderless composite boards for electromagnetic absorption via a facile and green method," Nanomaterials 8(1), 1-17. DOI: $10.3390 /$ nano8010052

Domínguez-Robles, J., Tarrés, Q., Alcalà, M., El Mansouri, N.-E., Rodríguez, A., Mutjé, P., and Delgado-Aguilar, M. (2020). "Development of high-performance binderless fiberboards from wheat straw residue," Construction and Building Materials 232, 1-11. DOI: 10.1016/j.conbuildmat.2019.117247

Dou, J., Kim, H., Li, Y., Padmakshan, D., Yue, F., Ralph, J., and Vuorinen, T. (2018). "Structural characterization of lignins from willow bark and wood," Journal of Agricultural and Food Chemistry 66(28), 7294-7300. DOI: 10.1021/acs.jafc.8b02014

Ferrandez-Garcia, C. C., Garcia-Ortuño, T., Ferrandez-Garcia, M. T., Ferrandez-Villena, M., and García, C. E. F. (2017). "Fire-resistance, physical, and mechanical characterization of binderless rice straw particleboards," BioResources 12(4), 85398549. DOI: 10.15376/biores.12.4.8539-8549 
Ferrandez-Villena, M., Ferrandez-Garcia, C. E., Garcia Ortuño, T., Ferrandez-Garcia, A., and Ferrandez-Garcia, M. T. (2019). "Study of the utilisation of almond residues for low-cost panels," Agronomy 9(12), 1-10. DOI: 10.3390/agronomy9120811

Ferrandez-Villena, M., Ferrandez-Garcia, C. E., Garcia-Ortuño, T., Ferrandez-Garcia, A., and Ferrandez-Garcia, M. T. (2020). "The influence of processing and particle size on binderless particleboards made from Arundo donax L. rhizome," Polymers 12(3), 112. DOI: $10.3390 /$ polym 12030696

Fiorelli, J., Bueno, S. B., and Cabral, M. R. (2019). “Assessment of multilayer particleboards produced with green coconut and sugarcane bagasse fibers," Construction and Building Materials 205, 1-9. DOI:

10.1016/j.conbuildmat.2019.02.024

Gao, Z., Wang, X.-M., Wan, H., and Brunette, G. (2011). "Binderless panels made with black spruce bark," BioResources 6(4), 3960-3972. DOI: 10.15376/biores.6.4.39603972

Geng, X., Zhang, S. Y., and Deng, J. (2006). "Alkaline treatment of black spruce bark for the manufacture of binderless fiberboard," Journal of Wood Chemistry and Technology 26(4), 313-324. DOI: 10.1080/02773810601076857

Golden, R. (2011). "Identifying an indoor air exposure limit for formaldehyde considering both irritation and cancer hazards," Critical Reviews in Toxicology 41(8), 672-721. DOI: 10.3109/10408444.2011.573467

Gonultas, O., and Ucar, M. B. (2013). "Chemical characteristics of the cone and wood of Pinus pinea," Lignocellulose 2(1), 262-269.

Gonultas, O., and Candan, Z. (2018). "Chemical characterization and FTIR spectroscopy of thermally compressed eucalyptus wood panels," Maderas Ciencia y Tecnología 20(3), 431-442. DOI: 10.4067/S0718-221X2018005031301

Gupta, G., Yan, N., and Feng, M. W. (2011). "Effects of pressing temperature and particle size on bark board properties made from beetle-infested lodgepole pine (Pinus contorta) barks," Forest Products Journal 61(6), 478-488. DOI: 10.13073/0015-7473-61.6.478

Gupta, P., and Maji, P. (2020). "Characterization of wood, cork and their composites for building insulation," Encyclopedia of Renewable and Sustainable Materials 2, 44-59. DOI: 10.1016/B978-0-12-803581-8.10591-0

Harkin, J. M., and Rowe, J. W. (1971). Bark and Its Possible Uses (Research Note FPL 091), U. S. Department of Agriculture, Forest Products Laboratory, Madison, WI.

Harun, J., and Labosky Jr., P. (2007). "Chemical constituents of five northeastern barks," Wood and Fiber Science 17(2), 274-280.

Hashim, R., Nadhari, W. N. A. W., Sulaiman, O., Kawamura, F., Hiziroglu, S., Sato, M., Sugimoto, T., Seng, T. G., and Tanaka, R. (2011). "Characterization of raw materials and manufactured binderless particleboard from oil palm biomass," Materials \& Design 32(1), 246-254. DOI: 10.1016/j.matdes.2010.05.059

Hidalgo-Cordero, J. F., García-Ortuño, T., and García-Navarro, J. (2020). “Comparison of binderless boards produced with different tissues of totora (Schoenoplectus californicus (C.A. Mey) Soják) stems," Journal of Building Engineering 27, 1-10. DOI: 10.1016/j.jobe.2019.100961

Hosseinihashemi, S. K., Shamspour, M.-H., Safdari, V., Pourmousa, S., and Ayrilmis, N. (2017). "The influences of poplar inner and outer bark content on mechanical properties of wood/polypropylene composites," Journal of the Chilean Chemical Society 62(1), 3365-3369. DOI: 10.4067/S0717-97072017000100012 
Iswanto, A. H., Febrianto, F., Hadi, Y. S., Ruhendi, S., and Hermawan, D. (2014). "The effect of pressing temperature and time on the quality of particle board made from jatropha fruit hulls treated in acidic condition," MAKARA Journal of Technology Series 17(3), 145-151. DOI: 10.7454/mst.v17i3.2930

Iswanto, A. H., Munthe, R., Darwis, A., Azhar, I., Susilowati, A., Prabuningrum, D. S., and Fatriasari, W. (2019). "Effect of several exterior adhesive types on dimensional stability of bamboo oriented particleboard," Korean Journal of Materials Research 29(5), 277-281. DOI: 10.3740/MRSK.2019.29.5.277

Jumhuri, N., Hashim, R., Sulaiman, O., Nadhari, W. N. A. W., Salleh, K. M., Khalid, I., Saharudin, N. I., and Razali, M. Z. (2014). "Effect of treated particles on the properties of particleboard made from oil palm trunk," Materials \& Design 64, 769774. DOI: 10.1016/j.matdes.2014.08.053

Kain, G., Güttler, V., Barbu, M.-C., Petutschnigg, A., Richter, K., and Tondi, G. (2014). "Density related properties of bark insulation boards bonded with tannin hexamine resin," European Journal of Wood and Wood Products 72(4), 417-424. DOI: 10.1007/s00107-014-0798-4

Krogell, J., Holmbom, B., Pranovich, A., Hemming, J., and Willför, S. (2012). "Extraction and chemical characterization of Norway spruce inner and outer bark," Nordic Pulp \& Paper Research Journal 27( 1), 6-17. DOI: 10.3183/npprj-2012-2701-p006-017

Kurokochi, Y., and Sato, M. (2020). "Steam treatment to enhance rice straw binderless board focusing hemicellulose and cellulose decomposition products," Journal of Wood Science 66(1), 1-8. DOI: 10.1186/s10086-020-1855-8

Lakreb, N., As, N., Gorgun, V., Sen, U., Gomes, M. G., and Pereira, H. (2018). "Production and characterization of particleboards from cork-rich Quercus cerris bark," European Journal of Wood and Wood Products 76(3), 989-997. DOI: 10.1007/s00107-017-1284-6

Liao, R., Xu, J., and Umemura, K. (2016). "Low density sugarcane bagasse particleboard bonded with citric acid and sucrose: Effect of board density and additive content," BioResources 11(1), 2174-2185. DOI: 10.15376/biores.11.1.2174-2185

Liu, L., Li, H., Lazzaretto, A., Manente, G., Tong, C., Liu, Q., and Li, N. (2017). “The development history and prospects of biomass-based insulation materials for buildings," Renewable and Sustainable Energy Reviews 69, 912-932.

DOI: 10.1016/j.rser.2016.11.140

Mahieu, A., Alix, S., and Leblanc, N. (2019). "Properties of particleboards made of agricultural by-products with a classical binder or self-bound," Industrial Crops and Products 130, 371-379. DOI: 10.1016/j.indcrop.2018.12.094

Mancera, C., El Mansouri, N.-E., Vilaseca, F., Ferrando, F., and Salvado, J. (2011). "The effect of lignin as a natural adhesive on the physico-mechanical properties of Vitis vinifera fiberboards," BioResources 6(3), 2851-2860. DOI: 10.15376/biores.6.3.28512860

Nadhari, W. N. A. W., Danish, M., Nasir, M. S. R. M., and Geng, B. J. (2019). "Mechanical properties and dimensional stability of particleboard fabricated from steam pre-treated banana trunk waste particles," Journal of Building Engineering 26, 1-4. DOI: 10.1016/j.jobe.2019.100848

Nasir, M., Khali, D. P., Jawaid, M., Tahir, P. M., Siakeng, R., Asim, M., and Khan, T. A. (2019). "Recent development in binderless fiber-board fabrication from agricultural residues: A review," Construction and Building Materials 211, 502-516. DOI: 
10.1016/j.conbuildmat.2019.03.279

Nitu, I. P., Islam, N., Ashaduzzaman, Amin, K., and Shams, I. (2020). "Optimization of processing parameters for the manufacturing of jute stick binderless particleboard," Journal of Wood Science 66(1), 1-9. DOI: 10.1186/s10086-020-01913-z

Nitu, I. P., Shams, I., Islam, N., Ratul, S. B., and Ashaduzzaman (2017). "Development of binderless composites from different nonwood lignocellulosic materials: Overview," in: Handbook of Ecomaterials, L. M. T. Martínez, O. V. Kharissova, and B. I. Kharisov (ed.), Springer International Publishing, Cham, Switzerland, pp. 1-15.

Nonaka, S., Umemura, K., and Kawai, S. (2013). "Characterization of bagasse binderless particleboard manufactured in high-temperature range," Journal of Wood Science 59(1), 50-56. DOI: 10.1007/s10086-012-1302-6

Okuda, N., Hori, K., and Sato, M. (2006). "Chemical changes of kenaf core binderless boards during hot pressing (I): Influence of the pressing temperature condition," Journal of Wood Science 52(3), 244-248. DOI: 10.1007/s10086-005-0761-4

Ozgenc, O., Durmaz, S., and Kuştaş, S. (2017). "Chemical analysis of tree barks using ATR-FTIR spectroscopy and conventional techniques," BioResources 12(4), 91439151. DOI: 10.15376/biores.12.4.9143-9151

Panyakaew, S., and Fotios, S. (2011). "New thermal insulation boards made from coconut husk and bagasse," Energy and Buildings 43(7), 1732-1739. DOI: 10.1016/j.enbuild.2011.03.015

Pásztory, Z., Mohácsiné, I. R., and Börcsök, Z. (2017). "Investigation of thermal insulation panels made of black locust tree bark," Construction and Building Materials 147, 733-735. DOI: 10.1016/j.conbuildmat.2017.04.204

Pásztory, Z., Börcsök, Z., and Tsalagkas, D. (2019). "Density optimization for the manufacturing of bark-based thermal insulation panels," in: Proceedings of the $5^{\text {th }}$ International Conference on Environment and Renewable Energy, 25-28 February, Ho Chi Minh City, Vietnam, pp. 1-6.

Pettersen, R. C. (1984). "The chemical composition of wood," in: The Chemistry of Solid Wood, R. Rowell (ed.) American Chemical Society, Washington, D.C., pp. 57-126.

Pintiaux, T., Viet, D., Vandenbossche, V., Rigal, L., and Rouilly, A. (2015). "Binderless materials obtained by thermo-compressive processing of lignocellulosic fibers: A comprehensive review," BioResources 10(1), 1915-1963. DOI:

10.15376/biores.10.1.1915-1963

Purwanto, D. (2015). "Sifat papan partikel dari kulit pohon galam (Melaleuca leucadendra) dengan perekat urea formaldehida [The properties of particleboard made of galam (Melaleuca leucadendra L.) tree bark bonded with urea formaldehyde]," Jurnal Penelitian Hasil Hutan 33(2), 135-144. DOI: 10.20886/jphh.2015.33.2.135-144

Romaní, A., Rocha, C. M. R., Michelin, M., Domingues, L., and Teixeira, J. A. (2020). "Chapter 20 - Valorization of lignocellulosic-based wastes," in: Current Developments in Biotechnology and Bioengineering - Resource Recovery from Wastes, S. Varjani, A. Pandey, E. Gnansounou, S. K. Khanal, and S. Raveendran (ed.), Elsevier, Amsterdam, Netherlands, pp. 383-410.

Roussan, P. E. H. (1923). "Application of the bark (suber) of Melaleuca leucadendron to thermic, hydraulic, and dielectric devices," U. S. Patent No. 4058101923.

Rowell, R. M., Pettersen, R., and Tshabalala, M. A. (2012). "Cell wall chemistry,” in: Handbook of Wood Chemistry and Wood Composites, R. M. Rowell (ed.), CRC Press, Boca Raton, FL, pp. 33-72. 
Sakai, K. (2000). "Chemistry of bark," in: Wood and Cellulosic Chemistry, D. N.-S. Hon and N. Shiraishi (ed.), Marcel Dekker, Inc., New York, NY, pp. 243-274.

Sakasegawa, M., Hori, K., and Yatagai, M. (2003). "Composition and antitermite activities of essential oils from Melaleuca species," Journal of Wood Science 49(2), 181-187. DOI: $10.1007 / \mathrm{s} 100860300029$

Santana, M. A. E., and Okino, E. Y. A. (2007). "Chemical composition of 36 Brazilian amazon forest wood species," Holzforschung 61(5), 469-477. DOI: 10.1515/HF.2007.084

Sato, M. (2008). "Development of appropriate utilization technology of Melaleuca wood in the Mekong Delta," in: Proceedings of the $10^{\text {th }}$ World Conference on Timber Engineering 2008, 2-5 June, Miyazaki, Japan, pp. 954-961.

Shi, J., Peng, J., Huang, Q., Cai, L., and Shi, S. Q. (2020). "Fabrication of densified wood via synergy of chemical pretreatment, hot-pressing and post mechanical fixation," Journal of Wood Science 66(1), 1-9. DOI: 10.1186/s10086-020-1853-X

SNI 03-2105-2006 (2006). "Papan partikel [Particleboard]," National Standardization Agency for Indonesia, Jakarta, Indonesia.

SNI 0492-2008 (2008). "Pulp dan kayu - Cara uji kadar lignin - Metode Klason [Pulp and wood - Test method for lignin content - Klason method]," National Standardization Agency for Indonesia, Jakarta, Indonesia.

SNI 14-1838-1990 (1990). "Cara uji kelarutan kayu dan pulp dalam larutan natrium hidroksida 1 persen [Test method for solubility of wood and pulp in 1 percent sodium hydroxide solution]," National Standardization Agency for Indonesia, Jakarta, Indonesia.

SNI 01-1305-1989 (1989). "Kayu, Cara uji kelarutan dalam air dingin dan air panas [Wood, Test methods of solubility in cold water and hot water]," National Standardization Agency for Indonesia, Jakarta, Indonesia.

SNI 8401:2017 (2017). "Ekstraktif terlarut pada kayu dan pulp [Solvent extractives of wood and pulp]," National Standardization Agency for Indonesia, Jakarta, Indonesia.

SNI ISO 776:2010 (2010). "Pulp - Cara uji kadar abu tidak larut asam [Pulps Determination of acid-insoluble ash]," National Standardization Agency for Indonesia, Jakarta, Indonesia.

Song, X., Wang, X., and Kito, K. (2020). "Effects of heating temperature on the properties of bio-board manufactured by using soybean straw," Materials 13(3), 1-14. DOI: $10.3390 / \mathrm{ma} 13030662$

Supriyati, W. (2015). Kualitas Kayu Gelam Sebagai Tiang Pancang Bangunan di Tanah Rawa Gambut [Gelam Wood Quality as Building Piles in Peat Swamp Land], Ph.D. Dissertation, University of Gadjah Mada, Yogyakarta, Indonesia.

Supriyati, W., Prayitno, T. A., Sumardi, S., and Marsoem, S. N. (2015). "Kearifan lokal penggunaan kayu Gelam dalam tanah rawa gambut di Kalimantan tengah [Local wisdom of utilization of Gelam wood on peatswamp land of Central Kalimantan]," Jurnal Manusia dan Lingkungan 22(1), 94-99. DOI: 10.22146/jml.18729

Sutrisno, Syamsudin, T. S., Alamsyah, E. M., and Purwasasmita, B. S. (2015). "Synthesis and characterization of bio-based nanomaterials from Jabon (Anthocephalus cadamba (Roxb.) Miq) wood bark: An organic waste material from community forest," Journal of Mathematical and Fundamental Sciences 47(2), 205218. DOI: 10.5614/j.math.fund.sci.2015.47.2.7

Vidil, L., Fiorelli, J., Bilba, K., Onésippe, C., Arsène, M. A., and Savastano, H. (2016). "Thermal insulating particle boards reinforced with coconut leaf sheaths," Green 
Materials 4(1), 31-40. DOI:10.1680/jgrma.15.00029

Wang, J., Liu, J., Ni, L., and Li, J. (2018). "Thermopressed binderless fiberboards from wheat straw by adding black liquor," Wood Research 63(6), 1021-1032.

Wang, J., Wang, B., Liu, J., Ni, L., and Li, J. (2019). "Effect of hot-pressing temperature on characteristics of straw-based binderless fiberboards with pulping effluent," Materials 12(6), 1-11. DOI: 10.3390/ma12060922

Widyorini, R., Nugraha, P. A., Rahman, M. Z. A., and Prayitno, T. A. (2016). "Bonding ability of a new adhesive composed of citric acid-sucrose for particleboard," BioResources 11(2), 4526-4535. DOI: 10.15376/biores.11.2.4526-4535

Wise, L. E. (1946). "Chlorite holocellulose, its fractionation and bearing on summative wood analysis and studies on the hemicelluloses," Paper Trade Journal 122(2), 3543.

Xiao, Y., Dong, H., Long, C., Zheng, M., Lei, B., Zhang, H., and Liu, Y. (2014). "Melaleuca bark based porous carbons for hydrogen storage," International Journal of Hydrogen Energy 39(22), 11661-11667. DOI: 10.1016/j.ijhydene.2014.05.134

Xu, J., Sugawara, R., Widyorini, R., Han, G., and Kawai, S. (2004). "Manufacture and properties of low-density binderless particleboard from kenaf core," Journal of Wood Science 50(1), 62-67. DOI: 10.1007/s10086-003-0522-1

Zhang, J., and Lin, Z. (2016). "Structure characteristics of self-bonding boards during hot press for leukemia inhibition," Saudi Pharmaceutical Journal 24(3), 312-317. DOI: $10.1016 /$ j.jsps.2016.04.003

Zhou, X., Zheng, F., Li, H., and Lu, C. (2010). "An environment-friendly thermal insulation material from cotton stalk fibers," Energy and Buildings 42(7), 1070-1074. DOI: $10.1016 / j$.enbuild.2010.01.020

Article submitted: December 29, 2020; Peer review completed: February 21, 2021; Revised version received and accepted: April 18, 2021; Published: April 29, 2021. DOI: 10.15376/biores.16.2.4171-4199 